\title{
An empirical-conceptual gully evolution model for channelled sea cliffs
}

\author{
Julian Leyland *, Stephen E. Darby \\ School of Geography, University of Southampton, Highfield, Southampton, S017 1BJ, United Kingdom
}

\section{A R T I C L E I N F O}

\section{Article history:}

Received 22 February 2008

Received in revised form 21 April 2008

Accepted 23 April 2008

Available online 8 May 2008

\section{Keywords:}

Gully

Coastal

Knickpoint

Channel evolution

Erosion modelling

Chines

\begin{abstract}
A B S T R A C T
Incised coastal channels are a specific form of incised channel that are found in locations where stream channels flowing to cliffed coasts have the excess energy required to cut down through the cliff to reach the outlet water body. The southern coast of the Isle of Wight, southern England, comprises soft cliffs that vary in height between 15 and $100 \mathrm{~m}$ and which are retreating at rates $\leq 1.5 \mathrm{~m} \mathrm{a}^{-1}$, due to a combination of wave erosion and landslides. In several locations, river channels have cut through the cliffs to create deeply $(\leq 45 \mathrm{~m})$ incised gullies, known locally as 'Chines'. The Chines are unusual in that their formation is associated with dynamic shoreline encroachment during a period of rising sea-level, whereas existing models of incised channel evolution emphasise the significance of base level lowering. This paper develops a conceptual model of Chine evolution by applying space for time substitution methods using empirical data gathered from Chine channel surveys and remotely sensed data. The model identifies a sequence of evolutionary stages, which are classified based on a suite of morphometric indices and associated processes. The extent to which individual Chines are in a state of growth or decay is estimated by determining the relative rates of shoreline retreat and knickpoint recession, the former via analysis of historical aerial images and the latter through the use of a stream power erosion model.
\end{abstract}

(c) 2008 Elsevier B.V. All rights reserved.

\section{Introduction}

Incised channels are features of disturbed landscapes that are found in all regions of the world (Darby and Simon, 1999). At the most fundamental level incision is a requirement of drainage network evolution and development, but it can also rejuvenate fluvial networks and lead to further landscape development (Simon and Darby, 1999). As such, the sediment output from a network of incised channels will often represent much of the sediment yield from a landscape (Schumm et al., 1984; Simon et al., 1996). The derived sediment is stored in bars, floodplains and terraces and therefore has a significant impact on downstream morphology and ecology. Increased suspended sediments and mobile streambeds, which affect water quality and spawning habitats, have a severe impact on in-stream ecology (Greig et al., 2005; Suren et al., 2005). The reduction of riparian vegetation through mass-wasting processes increases water temperatures due to reduced shade and degrades stream corridor habitat (Brookes, 1988).

In view of the importance of channel incision, it is not surprising that several models have been developed to predict the forms and processes associated with the evolution of incised channels. In these studies channel response is characterised through a series of different sequential changes at a set spatial location. For example, Schumm

\footnotetext{
* Corresponding author. Tel.: +44 2380 829076; fax: +44 2380593295.

E-mail addresses: J.Leyland@soton.ac.uk (J. Leyland), S.E.Darby@soton.ac.uk (S.E. Darby).
}

et al. (1984) used space-for-time substitution (SFTS) to identify a sequence of reach types on Oaklimiter Creek, Mississippi. The result was a schematic longitudinal profile with five corresponding reach cross-sections representing different stages of development. Following this lead other Channel Evolution Models (CEMs) have developed the Schumm et al. (1984) model further (e.g. Simon and Hupp, 1986; Watson et al., 1986). Significantly, Simon (1989) presented diagnostic bank slope development criteria to robustly identify each stage in the CEM.

Within the coastal zone (which here refers to land adjacent to both oceans and lakes) where cliffs are found, there is the potential for the formation of a specific type of incised channel or gully to form. Incised coastal channels occur where stream channels have the excess energy required to cut down through the cliff to reach the outlet water body. Stream channels that do not have the required energy to overcome resistance to erosion simply flow over the cliff to create a coastal waterfall, a type of hanging valley. Sea cliffs occur along $\sim 80 \%$ of the Earth's ocean coasts, with numerous similar features bordering lakes and other large water bodies (Emery and Kuhn, 1982). As such there are abundant examples of coastal gullies (e.g. Schumm and Phillips, 1986; Burkard and Kostaschuk, 1995; Hampton and Griggs, 2004; Bishop et al., 2005). These channels are of interest both in terms of their geomorphic functioning and their habitat value. For example, incised coastal channels offer a unique opportunity to study terrestrial-marine process interactions within a single gully system. Soft sea cliffs are also recognised as habitats of international importance (Howe, 2002) but, in creating steep river banks that extend inland from the mouth of the river, incised coastal channels 
effectively increase the extent of this resource. Moreover, the varying aspects (with respect to the coastline) and sheltered nature of the cliffs within the channels increases the diversity of that habitat.

Existing CEMs for incised river channels make a number of assumptions that may limit their transferability to the specific context of incised coastal channels or other gully systems. For example, existing CEMs tend to view incision as being initiated by a single, quasi-instantaneous, large-scale (i.e., catastrophic) disturbance whereas quasi-continuous cliff recession is acknowledged as a key driver of channel extension in incised coastal channels (Flint, 1982; Schumm and Phillips, 1986). Second, existing CEMs assume that the base level disturbance is spatially stable (i.e. base level remains in approximately the same place in the horizontal plane, but can vary in the vertical plane). In contrast, sea-cliff recession is inherently dynamic and as such the bed level disturbance within an incised coastal channel can be said to be spatially dynamic in both the horizontal and vertical planes. Finally, existing CEMs assume that downstream reaches are the first to progress through to restabilisation as the disturbance propagates upstream. However, incised coastal channels may be affected by ongoing cliff retreat such that the equilibrating downstream reaches anticipated by existing models may be truncated or disturbed. As such it appears unlikely that incised coastal channels will restabilise to the extent predicted by existing CEMs. Existing CEMs are often treated as normative successional models, and deviations from the classical stages viewed as aberrations from a natural sequence. Although our understanding of incised channels has, therefore, progressed to a stage where detailed conceptual models coupled with empirical expressions of rates and magnitudes of change have been produced, substantial modifications are required to make them applicable to incised coastal channels and other gully systems. To address this gap we herein present a new conceptual model of incised coastal channel evolution which recognises multiple, alternative developmental pathways. Whilst such a model will likewise no doubt be site specific to some extent, it is hoped that it contains elements that will prove transferable to other incised coastal channel systems.

\section{Study site description}

The research in this paper is focused on a specific set of incised coastal channels (known locally as 'Chines') located on the southwest coast of the Isle of Wight, southern England (Fig. 1). A review of the regional setting is presented below, followed by an outline of selected historical evidence that illustrates key aspects of the behaviour of the Chines.

\subsection{Regional setting}

The Isle of Wight is part of the geological structure known as the Hampshire Basin. The Island has a varied physiography, being split by a central east-west ridge, formed of a vertically dipping stratum of Upper Chalk. North of the ridge the geology is dominated by Oligocene sands, clays and shales, divided by small rivers which drain north into the Solent (Bird, 1997). To the south lies a truncated anticlinal basin mainly consisting of Lower Greensand formations. At St Catherine's Point (see Fig. 1) the land rises again with a cap of Chalk and a ledge of Gault Clay

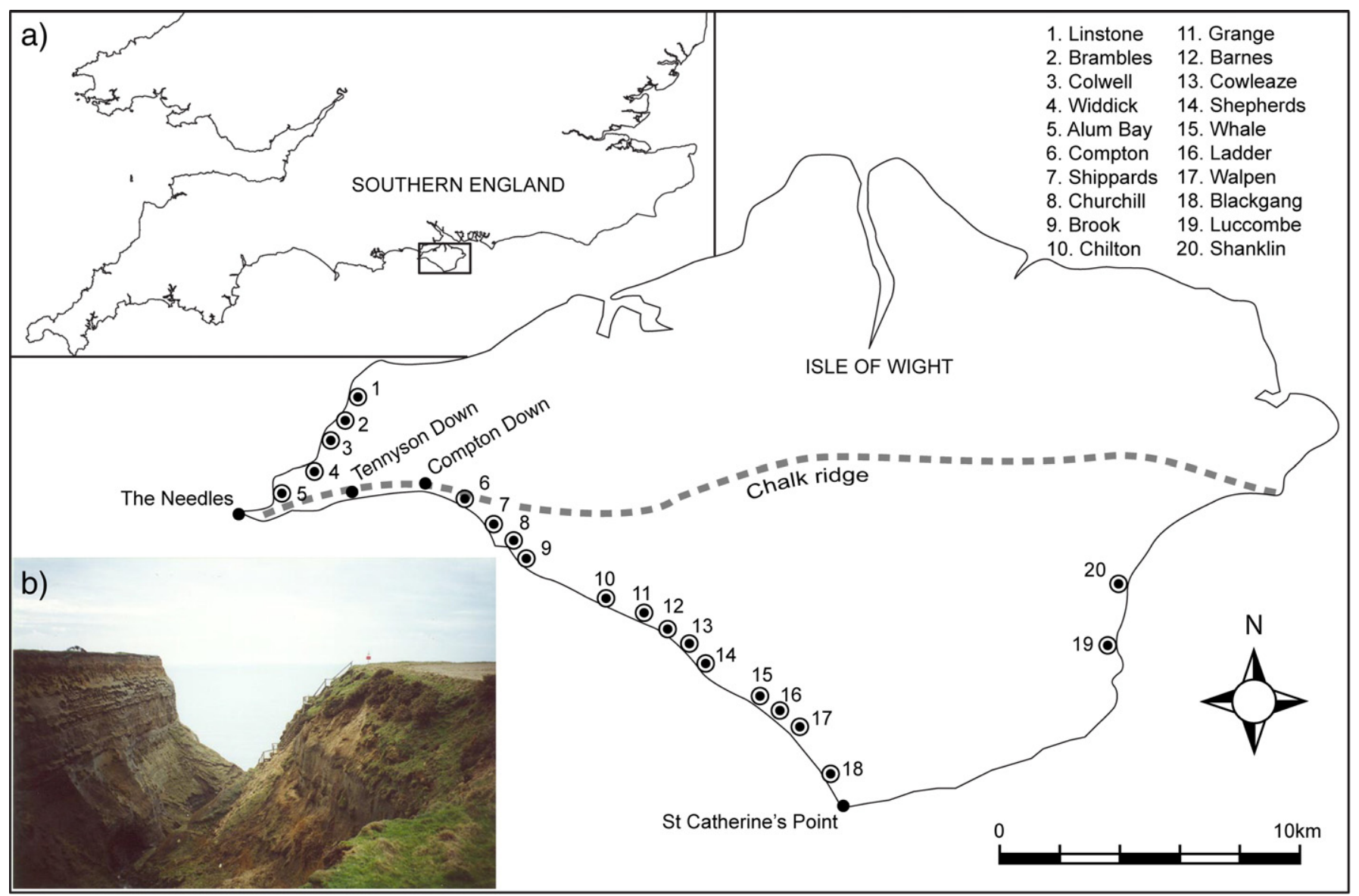

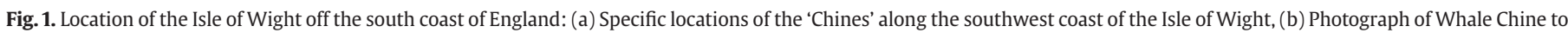
illustrate the scale of these erosional features. 
found at the base of the outcrop. The Chines of the southwest coast are found cut through the Gault Clay, Lower Greensand and Wealden Beds from Compton Down to St Catherine's Point (Daley and Insole, 1984).

Particularly relevant to the erosional history of the Chines is the sequence of sea-level changes during the late Quaternary and Holocene periods, which have been studied extensively for the British Isles as a whole (Lambeck, 1991; Clark and Mix, 2002; Shennan and Horton, 2002) and more locally (Nicholls, 1987; Long and Tooley, 1995; Velegrakis et al., 1999, 2000; Edwards, 2001). During glacial periods, when the sea-level was very low, a substantial easterly flowing river, the Solent, drained the Hampshire Basin (West, 1980; Barber, 1987; Nicholls, 1987; Tubbs, 1999). The basin was limited to the south by the Wight-Purbeck ridge, a chalk ridge that joined the two areas, the remnants of which are evident today in The Needles. The course of the Solent River is important as it explains many geological deposits of fluvial origin and it is likely that input tributaries, such as the western arm of the River Yar, would have been far more extensive. Pleistocene deposits suggest that a large river may have run somewhere along or south of the present southwest coast of the Isle of Wight, therefore it is unclear whether the Chines originally formed as part of this larger palaeo-system or whether they are exclusively contemporary features.

The rising sea-levels of the mid to late Holocene re-occupied former degraded cliffs re-initiating erosion of the soft Cretaceous sands and clays to form a rapidly retreating linear or slightly embayed cliff coastline. The retreating coastline has left a shallow near-shore shelf extending for $\sim 3 \mathrm{~km}$ and it is thought that this indicates the extent of the late Holocene coastal recession (Edwards, 2001). The recession has been restricted in certain localities by the occurrence of more resistant strata forming the northwest and southeast extremities of this section. The eroding coastline has truncated the northward flowing Western Yar, suggesting that much of the land lost to erosion was part of the drainage basin of the Western Yar.

\subsection{Historical evidence: Chines as dynamic channels}

The Chines are dynamic erosional features that by their very nature leave little evidence of their past morphology or historical rates of formation and evolution. Historical sources of information, such as maps, postcards and photographs, thus provide useful data regarding past flow routes and morphologies (Fig. 2). Through an understanding of both the drivers and rates of Chine extension or decay, an assessment of the relative stability of the Chines can be elucidated. Such an understanding is an essential basis from which to develop the CEM proposed herein (Section 3).

Evidence of Chine decay is abundant in the historical documents, for example Barber (1834) described the mouth of Blackgang Chine as a 22 m deep 'chasm' (Fig. 2a, see also Fig. 2c for similar morphology in 1847). By 1930 (Fig. 2b) this opening appears to have been lost to cliff recession, and presently Blackgang Chine has been almost completely destroyed. Similarly, in his visit to the island in 1824, Michael Faraday described accessing the beach through Walpen Chine (Bowers and Bowers, 1996). As early as 1847 Walpen Chine appeared to be in a state of decay, terminating in a waterfall or narrow fissure (Fig. 2d), while today this Chine hangs some $25 \mathrm{~m}$ above the shore platform. There is also a striking difference between Ladder Chine as depicted in Fig. 2e by Fitton (1847) and as it is seen today, a wind eroded bowl shaped feature that hangs approximately $35 \mathrm{~m}$ above the shore.

It is apparent from accounts, such as Fitton (1836) and White (1921), that the large gully that is today known as Shepherds Chine has formed wholly since about 1825 . According to these accounts and historical maps, prior to this date the stream flowed through Cowleaze Chine, some $0.3 \mathrm{~km}$ northwest. As the cliff retreated, the stream, which ran parallel to the coast for a short distance, was captured and a
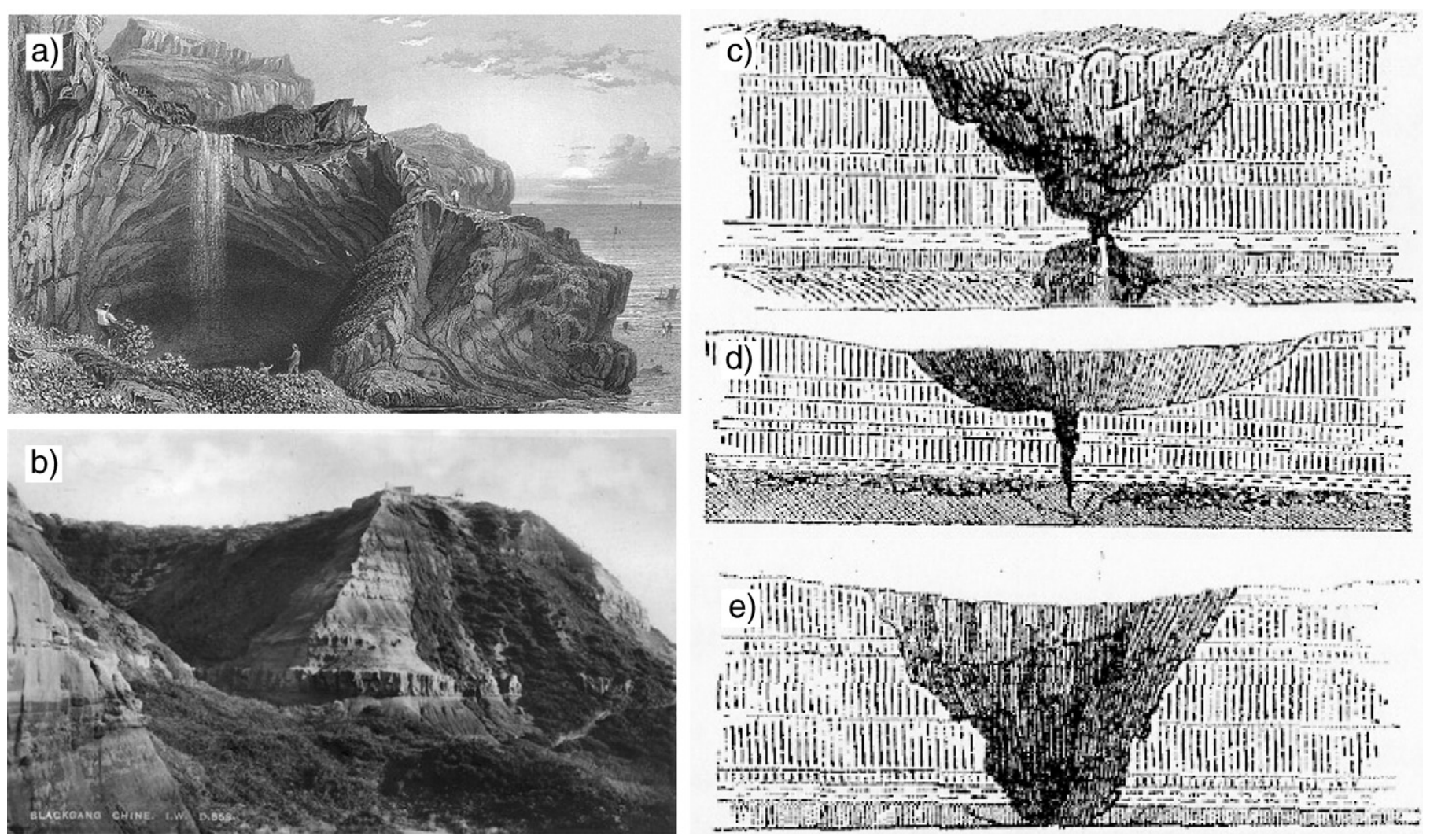

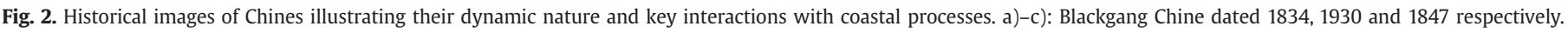

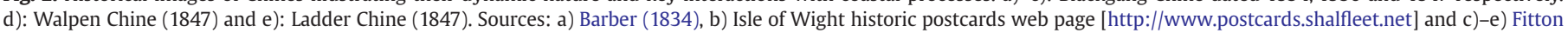
(1847). 


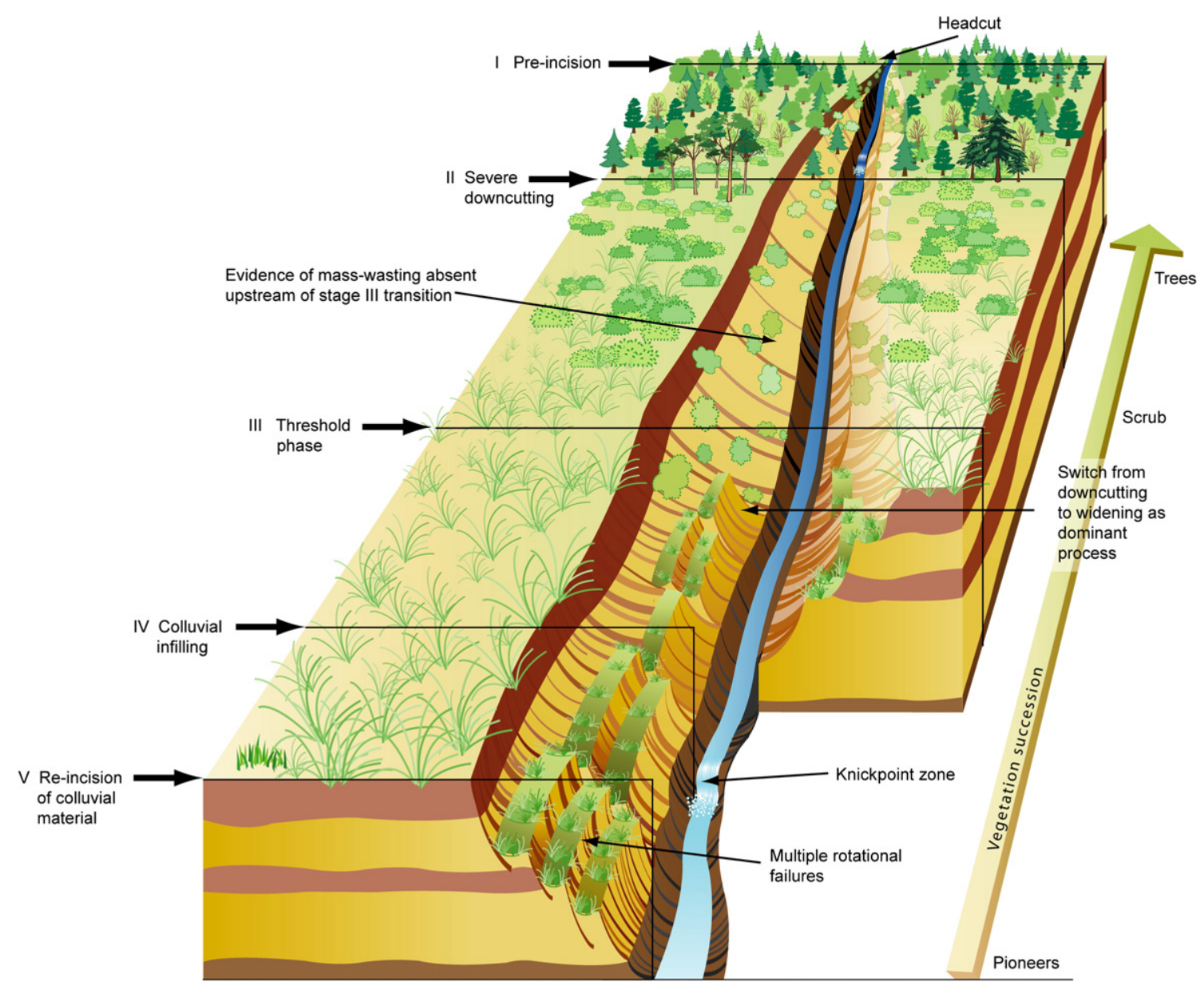

Fig. 3. Sketch indicating the relative arrangement of the postulated five key stages of the gully evolution model.

new Chine (Shepherds) formed. Observations from recent field visits and contemporary maps reveal that today no traces of this channel remain and that what is left of Cowleaze Chine terminates in a waterfall $\sim 14 \mathrm{~m}$ high. Rapid development is also evident at Whale Chine which, based on information derived from historical maps, has extended by a distance of $\sim 0.2 \mathrm{~km}$ since 1810 .

The evidence that the Chines are today found in various states emphasises that a dynamic interplay exists between the opposing tendencies to extend (via headward migration) or decay (via sea-cliff erosion truncating the seaward extent of the channels). In fact sea-cliff retreat plays a role in both these processes. On the one hand cliff recession destroys the Chines, while on the other cliff retreat creates locally oversteepened reaches (knickpoints) which, if stream power allows, can migrate upstream to extend the Chine headwards. Thus, extending Chines are associated with knickpoint retreat rates that are more rapid than the cliff retreat rate, and vice versa for decaying Chines. If the two rates are approximately equal then the Chine length remains dynamically constant.

\section{Development of a channel evolution model for incised coastal channels}

It can be assumed that the Chines are destabilised and evolve primarily by headward erosion associated with knickpoints created by episodes of cliff retreat. This assertion is clearly supported by the historical evidence presented above, and field observations of multiple knickpoint locations within the Chines. As such the method of SFTS as utilised by Schumm et al. (1984), Watson et al. (1986) and Simon and Hupp (1986) was employed in this research to develop a new incised coastal CEM. Specifically, initial field observations indicated that there is a clear spatial succession of forms in the Chines, progressing from relatively old near the mouth of the features to relatively new further inland. This distinctive spatial sequence enables us to postulate a fivestage model (I=youngest, V=oldest; Fig. 3) as follows:

I. Pre-incision - associated with 'undisturbed' reaches located upstream of the headcut.

II. Severe downcutting - incised reaches located immediately downstream of the headcut.

III. Threshold - located further downstream, associated with reaches that have been incised sufficiently to trigger masswasting.

IV. Colluvial infilling - located further downstream again and associated with reaches in which colluvially derived material from mass-wasting has temporarily infilled the channel.

V. Re-incision - found close to the mouth of the feature, and associated with re-incision of the colluvial infills.

To identify whether these postulated stages can be discriminated more robustly, and to elucidate further details about each stage of evolution, topographic surveys were carried out to obtain high resolution cross-sections and long profiles. However, due to the steep morphology and dense vegetation in some Chines, it was not always possible to complete ground-based surveys. Consequently light detection and ranging (LIDAR) data at a ground resolution of $2 \mathrm{~m}$ were also employed. An assessment of the accuracy of the LIDAR data was undertaken by comparing cross-sections derived from the LIDAR data with eight cross-sections obtained from the ground-based survey. Results show a good correlation $\left(r^{2}=0.95, n=349, P<0.001\right)$ between the two sets of data, with an absolute mean error ( \pm one standard deviation) 

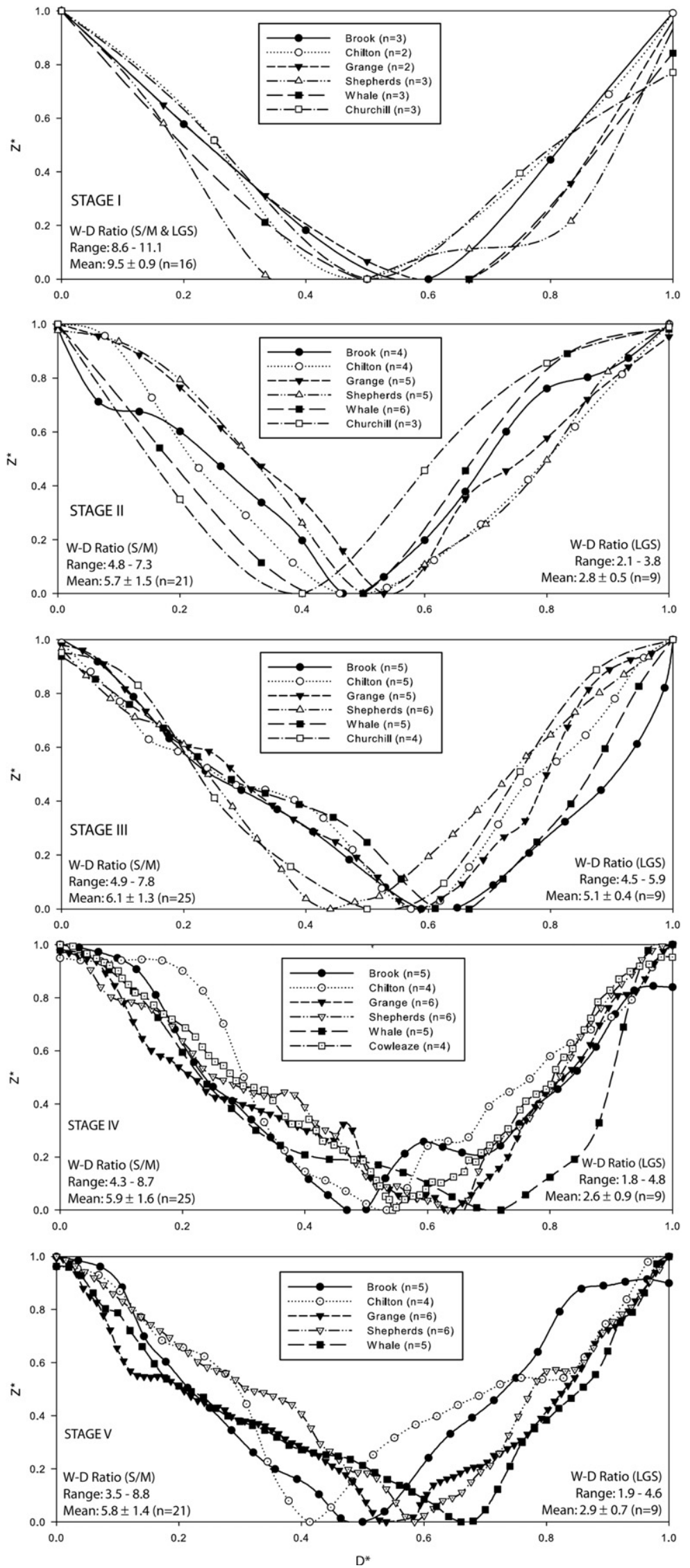

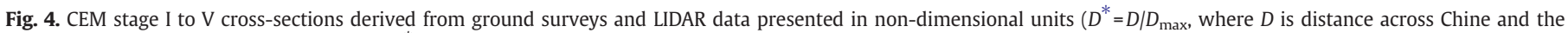

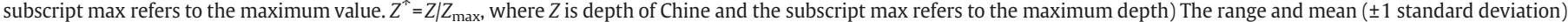

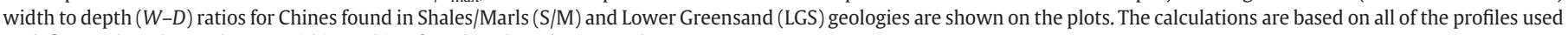
to define each archetypal stage within a Chine found in the relevant geology. 
of $0.43 \pm 0.26 \mathrm{~m}$. This error is small in relation to the high (up to $45 \mathrm{~m}$ ) vertical relief and steep $\left(0.3 \pm 0.1 \mathrm{~m}^{-1}\right)$ long profile gradient of the Chines. The use of LIDAR data was, therefore, deemed acceptable for the purposes of deriving cross-sections and long profiles to characterise morphological features within the Chines.

Five specific Chines (Brook, Chilton, Grange, Shepherds and Whale; see Fig. 1) were used to further develop the model. These were carefully selected using observations made during field visits and other secondary data to ensure that only unmodified Chines were used. Using the LIDAR data, cross-sections were extracted from the five selected Chines at intervals of every 10 channel widths. This yielded $\sim 25$ cross-section profiles per Chine (137 in total) ranging from the mouth to the undisturbed channel inland. These were grouped into sets of similar cross-section shape, enabling: (i) consideration of the extent of morphological changes between postulated evolutionary stages and (ii) quantitative analysis of morphometric attributes within each postulated stage. This process allowed a series of archetypal profiles to be defined for each of the postulated stages of development (Fig. 4). Note that Fig. 4 utilises non-dimensional axes to facilitate comparisons of the morphology of equivalent evolutionary stages within Chines of different scales.

Using the archetypal cross-section profiles (Fig. 4) the main morphological characteristics of each evolutionary stage were synthesised into a more detailed conceptual model (Fig. 5). Each of the stages represents a distinct set of morphological characteristics and associated processes. It should be noted that a specific Chine may or may not exhibit all five of the evolutionary stages illustrated in Fig. 5. Moreover, we also discriminate between (i) stable or growing Chines (stages I $-\mathrm{V}$ on Fig. 5), in which the mean rate of knickpoint recession is greater than or equal to the mean rate of cliff retreat and (ii) decaying Chines (stages DII - DV on Fig. 5), in which the knickpoint retreat rate is less than the cliff retreat rate. Note that decaying Chines do not pass through the sequential stages of development; instead evidence of latter stage morphology is removed as cliff retreat truncates the feature. Fig. 5 also indicates that Chines may switch from stable to decaying states, for example due to stream capture, or locally increased rates of cliff recession.

The model also attempts to account for variations in the morphological characteristics of each evolutionary stage that are induced by variations in lithological controls. These are explicitly represented by showing how the latter phase morphology of the Chines that cut through the Lower Greensand (LGS) geological unit (e.g. Whale Chine) varies compared to Chines located within the Shales and Marls. Any incisional stage within the model could reasonably be observed in the Lower Greensand unit so that in practical use the model would denote a decaying stage III reach found in Lower Greensand as a D-III-LGS reach.

\subsection{Stage I channels}

The pre-incisional stage proposed here is in essence functionally (if not morphologically) identical to the pre-modified stage I of the Schumm et al. (1984), Watson et al. (1986) and Simon and Hupp (1986) models. Stage I reaches are located upstream of the headcut that delimits the inland extent of incision within a Chine. The channel cross-section is 'u' shaped, with a fairly flat bed section (Fig. 4) and with bank heights of $<1.5 \mathrm{~m}$ above the low-flow water surface. The

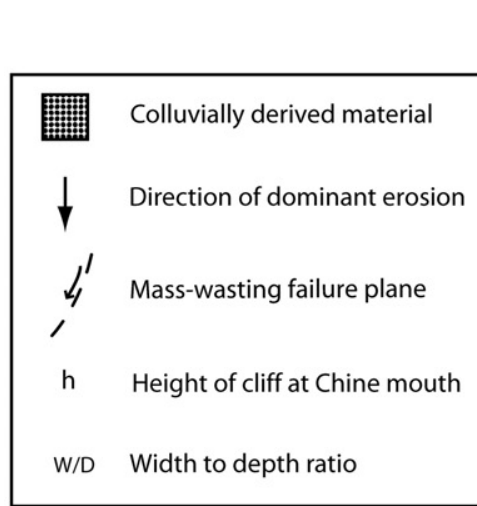

Lithological controls on stage morphology - LGS = Lower Greensand.

\section{Examples:}

IV LGS

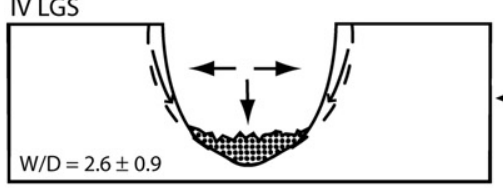

\section{VLGS}

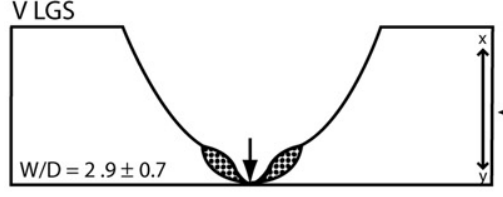

1.Stable/Growing Chine Wealden Shales/Marls

I- Pre-incision

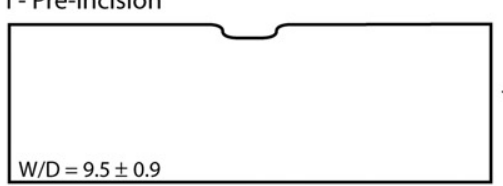

II - Severe downcutting

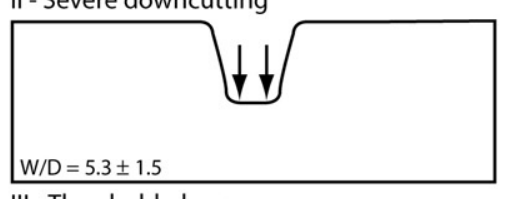

III - Threshold phase

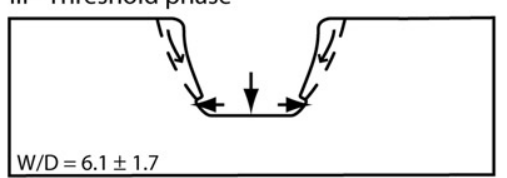

$\mathrm{W} / \mathrm{D}=6.1 \pm 1.7$

IV - Colluvial infilling due to local mass wasting
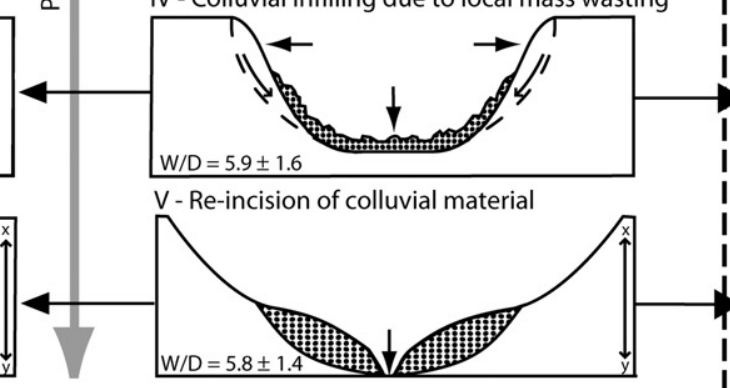

2. Decaying Chine

I

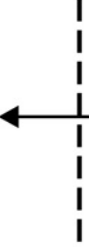

I

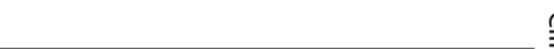

(1)

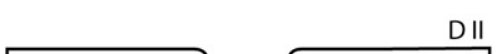

DII
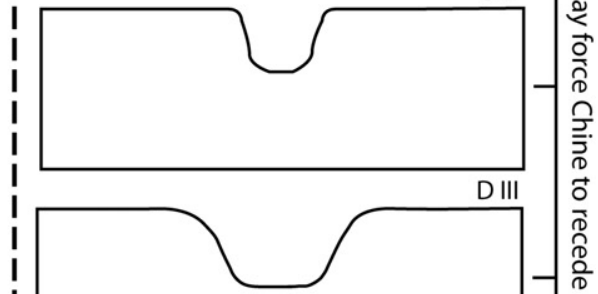
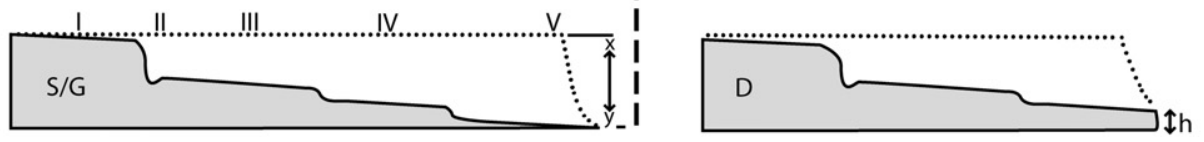

Fig. 5. CEM for incised coastal channels on the Isle of Wight. 

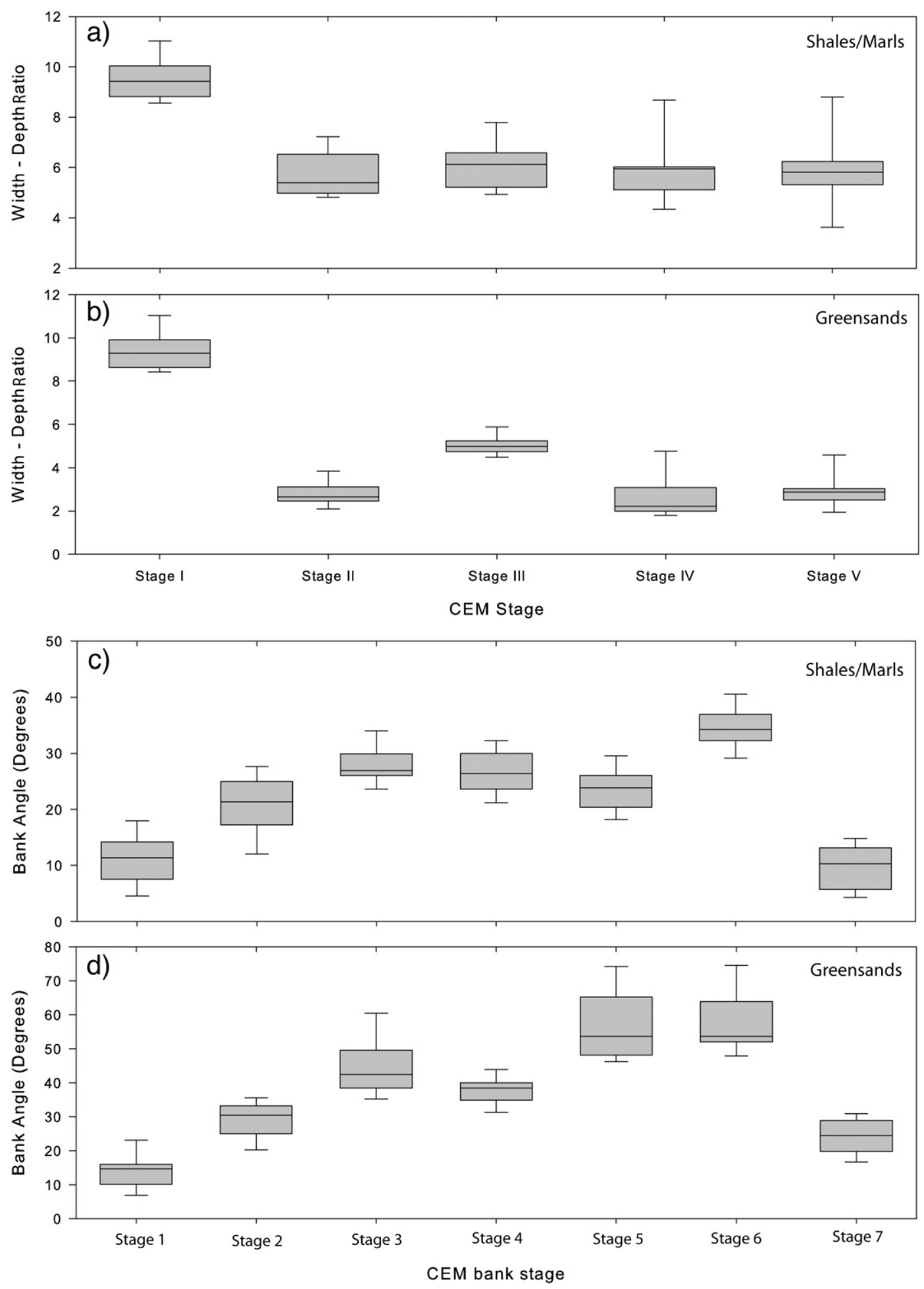

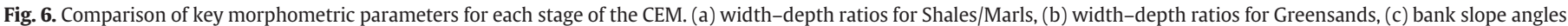

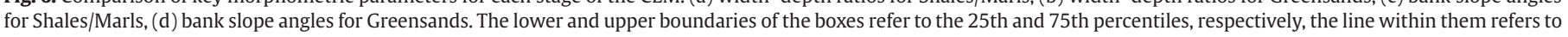
the median value; while the whiskers indicate the 10th and 90th percentiles. The bank slope stages are defined in the text.

banks are often densely vegetated, with mean bank angles of $\sim 11^{\circ} \pm 5^{\circ}$, well below the critical threshold required to induce mass-wasting. Width-to-depth ratios are also fairly high (mean value of $9.5^{\circ} \pm 0.9^{\circ}$ across all lithological units; Fig. 6). In contrast to other published models, however, for the Chines on the Isle of Wight, stage I reaches are characterised by streams that drain small $\left(<12 \mathrm{~km}^{2}\right)$ upstream areas and hence their bankfull channel widths are relatively small, ranging from $\sim 0.5-1.5 \mathrm{~m}$.

\subsection{Stage II channels}

Stage II reaches are located immediately downstream of the knickpoint that delimits the inland extent of incision. These reaches are characterised by rapid lowering of the Chine bed, induced by the recent passage of the knickpoint upstream, but the magnitude of the incision is insufficient to trigger mass-wasting of the channel banks. Chine stage II reaches can therefore be regarded as delimiting the 
Table 1

Statistical analysis of bank slope angles associated with each stage of the CEM

\begin{tabular}{|c|c|c|c|c|c|}
\hline \multirow[b]{2}{*}{$\begin{array}{l}\text { CEM } \\
\text { stage }\end{array}$} & \multirow[b]{2}{*}{$\begin{array}{l}\text { Bank slope } \\
\text { category }\end{array}$} & \multicolumn{2}{|c|}{ Shales and Marls } & \multicolumn{2}{|c|}{ Lower Greensands } \\
\hline & & $\begin{array}{l}\text { Mean } \\
\text { bank angle } \\
\text { (degrees) }\end{array}$ & $\begin{array}{l}\text { Tukey- } \\
\text { Kramer } \\
\text { grouping }\end{array}$ & $\begin{array}{l}\text { Mean } \\
\text { bank angle } \\
\text { (degrees) }\end{array}$ & $\begin{array}{l}\text { Tukey- } \\
\text { Kramer } \\
\text { grouping }\end{array}$ \\
\hline I & 1 & 11.1 & A & 11.1 & A \\
\hline II & 2 & 20.4 & B & 29.3 & B \\
\hline III-V & 3 & 34.5 & $\mathrm{C}$ & 57.9 & $\mathrm{C}$ \\
\hline III & 4 & 28.2 & B & 45.2 & B \\
\hline IV & 5 & 26.7 & B & 37.6 & B \\
\hline IV-V & 6 & 9.5 & A & 24.3 & B \\
\hline V & 7 & 23.5 & B & 57.6 & $\mathrm{C}$ \\
\hline
\end{tabular}

Means with the same Tukey-Kramer grouping letter are not significantly different from each other (Tukey-Kramer post-hoc test, $P<0.05$ ). Bank slope categories are defined in the text.

extent of development of the feature inland and marking a transition from the pre-incisional stage I channel to stage III channels located further downstream. Morphologically, Stage II reaches are charac- terised by ' $v$ ' shaped cross-sections (Fig. 4), with steeper bank angles (mean values of $20^{\circ} \pm 7^{\circ}$ in the Shales and Marls and $29^{\circ} \pm 6^{\circ}$ in the Lower Greensands, respectively) and lower width-depth ratios (mean values of $5.3 \pm 1.5$ in the Shales and Marls and $2.8 \pm 0.5$ in the Lower Greensands) distinguishing them from the stage I reaches upstream (Fig. 6).

\subsection{Stage III channels}

As incision progresses, bank heights and angles eventually attain critical values and widening is initiated. It is the onset of masswasting and widening that characterises stage III Chine channels. The switch to widening means that width to depth ratios, relative to stage II channels, (temporarily) increase to mean values of $6.1 \pm 1.7$ and $5.1 \pm 1.4$ for channels located in the Wealden and Lower Greensand beds, respectively (Fig. 6). In agreement with the observations of Simon and Hupp (1992), the most commonly observed bank failures are a combination of planar and small localised rotational,
Values given are sample ranges, starred values indicate mean slope angle \pm standard deviation (all bank angles in degrees). $n=$ number of values.

I - Pre-incision

Bank stage 1- pre-incision bank:

$5.1-21.2 * 11.2 \pm 4.8(n=75)$

$\mathrm{W} / \mathrm{D}=9.5 \pm 0.9$

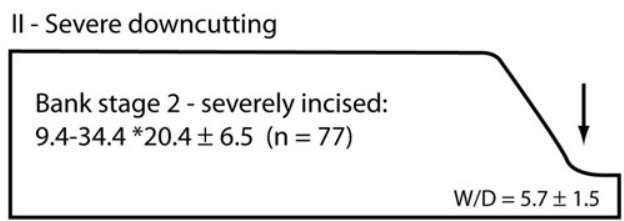

III - Threshold phase

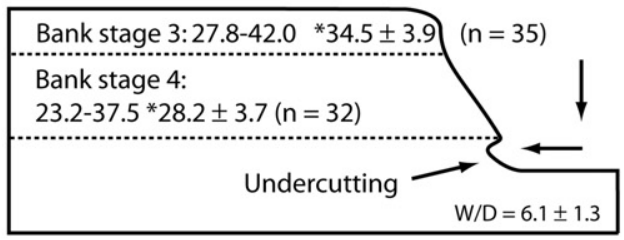

IV - Colluvial infilling due to local mass wasting

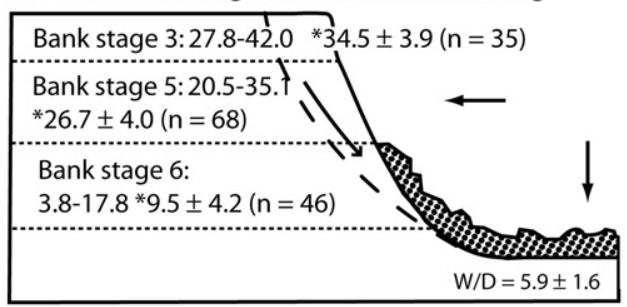

V - Re-incision of colluvial material

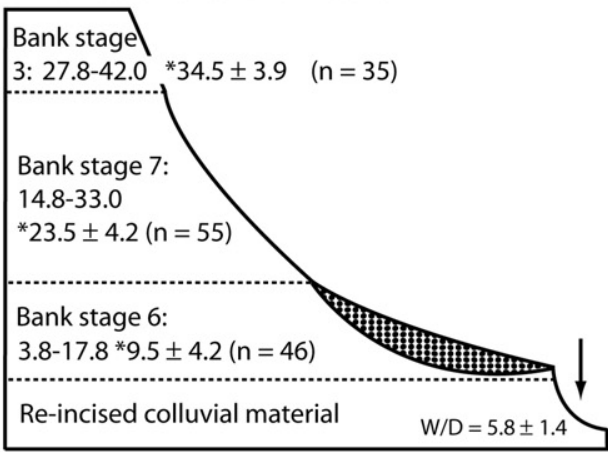

Colluvially derived material

1 Direction of

$\downarrow$ dominant erosion

W/D Width to depth ratio

\section{LGS - Lower GreenSand}

Bank stage 2 - severely incised: 17.1-38.6

${ }^{*} 29.3 \pm 5.7(n=21)$

$W / D=2.8 \pm 0.5$

\section{LGS}

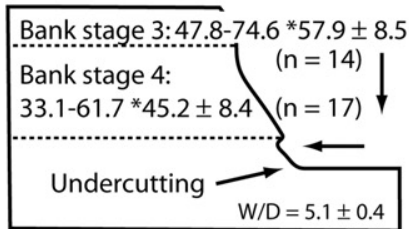

IV LGS

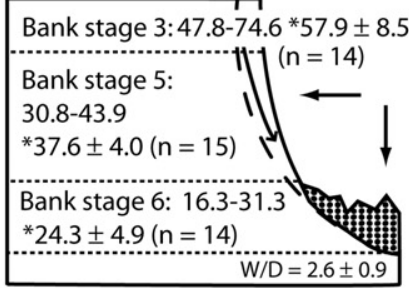

V LGS

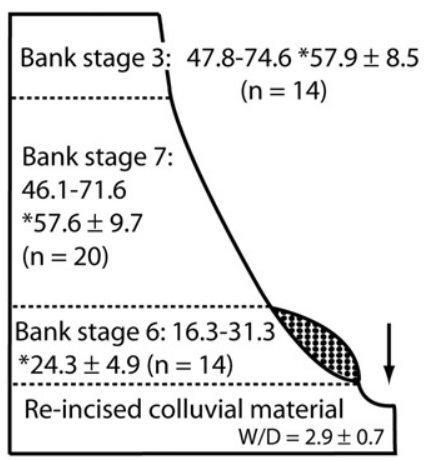

Fig. 7. Bank slope development characteristics associated with the five stages of the CEM developed for the Chines. Note scale is relative. 
with larger rotational failures more prevalent in stage IV and V reaches. Fig. 4 indicates that the bank morphology of stage III reaches becomes more complex, with the exposed failure surfaces creating: (i) a steeper (mean angles of about $35^{\circ} \pm 4^{\circ}$ for the Shales and Marls and $58^{\circ} \pm 9^{\circ}$ for the Lower Greensand) face (later referred to as bank slope category 3 in Table 1) near the top of the bank where planar failures dominate, and; (ii) less steep $\left(28^{\circ} \pm 4^{\circ}\right.$ and $45^{\circ} \pm 9^{\circ}$, respectively, highlighting the more cohesive nature of the Lower Greensand lithology) 'mass-wasted banks' (bank slope category 4 in Table 1) adjoining the channel, where a combination of small rotational failures and fluvially undercut planar failures dominate. On Fig. 4 this is particularly evident for the left banks (looking into the diagram) where a distinct break of slope, marking the transition between the upper (planar failures) and lower (rotational and planar failures) parts of the banks, is visible.

\subsection{Stage IV channels}

As the bed elevation continues to lower and stage III masswasting processes occur, at a certain point there is a switch in the dominant type of bank mass-wasting from the planar slab failures, dominant in stage III, to the larger scale rotational failures evident in stage IV (planar failures being restricted to the near channel and steeper upslope sections of the bank). The effects of these rotational failures are significant, as they temporarily lead to bed aggradation through the input of large volumes of colluvially derived sediment. Mean bank angles on the upper part of the slopes (bank slope category 5 in Table 1 ) remain similar to those of stage III channels $\left(27^{\circ} \pm 4^{\circ}\right.$ for Shales/Marls and $38^{\circ} \pm 4^{\circ}$ for Lower Greensand) due to the comparable failure mechanisms, but a new shelf-like break of slope (bank slope category 6 in Table 1), attributable to the infill, is evident on the cross-section profiles (Fig. 4). The mean slopes of these infill deposits have values of around $10^{\circ} \pm 4^{\circ}$ for the Shales and Marls, and $24^{\circ} \pm 5^{\circ}$ for the Lower Greensand (Fig. 6). Width to depth ratios appear to decrease slightly from those observed in stage III, with mean values of $5.9 \pm 1.6$ and $2.6 \pm 0.9$ for the Shales/Marls and Lower Greensand, respectively.

Although stage IV Chine channels and their counterparts in existing CEMs (e.g. Schumm et al., 1984; Watson et al., 1986; Simon and Hupp, 1986) are similar (both represent a functional situation in which sediment begins to be deposited on the channel bed, promoting a local recovery from the incision), important distinctions related to the mode of deposition can be noted. Specifically, although previous models emphasise that the deposited sediment is derived from bed and bank erosion in reaches upstream, in the Chines the deposition is sourced primarily as local colluvium. This reflects the points that: (i) the contributing drainage areas of the Chines tend to be too small to provide a significant upstream source of sediment, but that this is compensated for by (ii) the presence of very high side cliffs ( $\leq 40 \mathrm{~m}$ in some locations, see Fig. $1 \mathrm{~b}$ ) that, when destabilised, can deliver large volumes of sediment.

\subsection{Stage V channels}

Following the stream-bed deposition in stage IV, stage V Chines are characterised by a process of re-incision through the failed material. In well developed features, such as Shepherds Chine, this can create an interesting topography, analogous to 'interlocking spurs', as the sinuous stream re-incises the colluvial infill. This stage again contrasts with those of previously published models in that it is essentially another degradational stage, not a re-established equilibrium. Stage V Chine channels are, therefore, particularly complex morphologically (Fig. 4) as they include relic portions inherited from previous evolutionary stages, as well as the forms and processes associated with this re-incisional phase.

\subsection{Bank slope categories}

It is evident from the preceding that the onset of mass-wasting (Stages III and IV) and subsequent re-incision (Stage V) creates complex, composite, cross-section profiles (Fig. 4) in which different processes and their associated forms may be located within the same evolutionary stage. To account for this complexity, and following Simon (1989), the CEM proposed in Fig. 5 is supplemented with a classification of bank slope process-form units within each stage of the postulated CEM (Fig. 7 and Table 1). Bank slope categories 1 and 2 define the linear pre-incisional bank, and the onset of severe linear incision of CEM stages I and II, respectively. The banks of stages III-V, however, are a composite of distinct bank slope units. Bank slope category 3 denotes the steep face found at the tops of the banks in CEM stages III-V, denoted by Simon and Hupp (1986) as

Table 2

Detailed diagnostic criteria for CEM stages I to V for both Shales and Marls and Lower Greensands

\begin{tabular}{|c|c|c|c|c|c|c|c|c|c|c|}
\hline \multirow{2}{*}{$\begin{array}{l}\text { Stage } \\
\text { number }\end{array}$} & \multirow{2}{*}{$\begin{array}{l}\text { Bed-level } \\
\text { adjustment } \\
\text { type }\end{array}$} & \multirow{2}{*}{$\begin{array}{l}\text { Location } \\
\text { in feature }\end{array}$} & \multirow{2}{*}{$\begin{array}{l}\text { Process on } \\
\text { channel bed }\end{array}$} & \multirow{2}{*}{$\begin{array}{l}\text { Active } \\
\text { widening }\end{array}$} & \multirow{2}{*}{$\begin{array}{l}\text { Failure } \\
\text { types }\end{array}$} & \multirow{2}{*}{$\begin{array}{l}\text { Bank } \\
\text { slope } \\
\text { category }\end{array}$} & \multicolumn{2}{|l|}{ Shales and Marls } & \multicolumn{2}{|l|}{ Lower Greensands } \\
\hline & & & & & & & $\begin{array}{l}\text { Range, mean }(*) \text { and } \\
\text { standard deviation } \\
\text { of bank angles, in } \\
\text { degrees }\end{array}$ & $\begin{array}{l}\text { Range, mean }(*) \\
\text { and standard } \\
\text { deviation of width } \\
\text { to depth ratios }\end{array}$ & $\begin{array}{l}\text { Range, mean }(*) \text { and } \\
\text { standard deviation } \\
\text { of bank angles, in } \\
\text { degrees }\end{array}$ & $\begin{array}{l}\text { Range, mean }(*) \\
\text { and standard } \\
\text { deviation of width } \\
\text { to depth ratios }\end{array}$ \\
\hline $\mathrm{I}$ & $\begin{array}{l}\text { Pre- } \\
\text { modified }\end{array}$ & $\begin{array}{l}\text { Upstream of } \\
\text { headcut }\end{array}$ & $\begin{array}{l}\text { Transport of } \\
\text { sediment or mild } \\
\text { aggradation }\end{array}$ & No & - & 1 & $5-21 * 11 \pm 5(n=75)$ & $\begin{array}{l}8.6-11.1 * 9.5 \pm 0.9 \\
(n=16)\end{array}$ & $5-21 * 11 \pm 5(n=75)$ & $\begin{array}{l}8.6-11.1 * 9.5 \pm 0.9 \\
(n=16)\end{array}$ \\
\hline II & - & Headcut & Degradation & No & - & 2 & $9-34 * 20 \pm 7(n=77)$ & $\begin{array}{l}4.8-7.3 * 5.7 \pm 1.5 \\
(n=21)\end{array}$ & $17-39 * 29 \pm 6(n=21)$ & $\begin{array}{l}2.1-3.8 * 2.8 \pm 0.5 \\
(n=9)\end{array}$ \\
\hline \multirow[t]{2}{*}{ III } & $\begin{array}{l}\text { Migrating } \\
\text { degradation }\end{array}$ & $\begin{array}{l}\text { Downstream } \\
\text { of stage II }\end{array}$ & Degradation & Yes & Planar & 3 & $28-42 * 35 \pm 4(n=35)$ & $\begin{array}{l}4.9-7.8 * 6.1 \pm 1.3 \\
(n=25)\end{array}$ & $48-75 * 58 \pm 9(n=14)$ & $\begin{array}{l}4.5-5.9 * 5 \pm 0.4 \\
(n=9)\end{array}$ \\
\hline & & & & & Rotational & 4 & $23-38 * 28 \pm 4(n=32)$ & - & $33-62 * 45 \pm 8(n=17)$ & - \\
\hline \multirow[t]{3}{*}{ IV } & $\begin{array}{l}\text { Migration } \\
\text { degradation }\end{array}$ & Near mouth & $\begin{array}{l}\text { Temporary } \\
\text { aggradation }\end{array}$ & Yes & $\begin{array}{l}\text { Planar } \\
\text { cantilever }\end{array}$ & 3 & $28-42 * 35 \pm 4(n=35)$ & $\begin{array}{l}4.3-8.7 * 5.9 \pm 1.6 \\
(n=25)\end{array}$ & $48-75 * 58 \pm 9(n=14)$ & $\begin{array}{l}1.8-4.8 * 2.6 \pm 0.9 \\
(n=9)\end{array}$ \\
\hline & & & & & $\begin{array}{l}\text { Rotational } \\
\text { seepage }\end{array}$ & 5 & $21-35 * 27 \pm 4(n=68)$ & - & $31-44 * 38 \pm 4(n=15)$ & - \\
\hline & & & & & & 6 & $4-18 * 10 \pm 4(n=46)$ & - & $16-31 * 24 \pm 5(n=14)$ & - \\
\hline \multirow[t]{3}{*}{ V } & Migrating & $\begin{array}{l}\text { Near/at } \\
\text { mouth }\end{array}$ & Degradation & Yes & $\begin{array}{l}\text { Planar, } \\
\text { contilever }\end{array}$ & 3 & $28-42 * 36 \pm 4(n=35)$ & $\begin{array}{l}3.5-8.8 * 5.8 \pm 1.4 \\
(n=21)\end{array}$ & $48-75 * 58 \pm 9(n=14)$ & $\begin{array}{l}1.9-4.6 * 2.9 \pm 0.7 \\
(n=9)\end{array}$ \\
\hline & & & & & $\begin{array}{l}\text { Rotational } \\
\text { seepage }\end{array}$ & 7 & $15-33 * 24 \pm 4(n=35)$ & - & $\begin{array}{l}46-72 * 58 \pm 10 \\
(n=20)\end{array}$ & - \\
\hline & & & & & - & 6 & $4-18 * 10 \pm 4(n=46)$ & - & $\begin{array}{l}46-72 * 58 \pm 10 \\
(n=14)\end{array}$ & - \\
\hline
\end{tabular}

Starred values indicate mean ( \pm 1 standard deviation) and $n$ is the number of values used for calculations. 
the 'vertical face'. Bank slope category 4 denotes the mass-wasted banks adjoining the channel in stage III of the CEM. Bank slope category 5 defines the steeper bank section found between categories 3 and 6 in CEM stage IV, referred to as the 'upper bank' by Simon and Hupp (1986). Bank slope category 6 represents the colluvial infills of CEM stages IV and V and category 7 denotes the steeper 'upper bank' of CEM stage V. This classification supports the formal analysis of morphometric criteria used to discriminate CEM stages undertaken in the next section.

\section{Diagnostic criteria for the channel evolution model stages}

Although Fig. 4 allows the identification of changes between CEM stages, there is considerable variability of cross-section forms within each evolutionary stage. Consequently, analysis of cross-sectional profiles cannot by itself offer a robust means of discriminating each stage. In view of this, we tested the hypothesis that selected morphometric criteria can discriminate CEM stages by undertaking statistical analysis of variations in: (i) width to depth ratios and (ii) bank slope angles for each stage of channel evolution.

In fact, the data show that for Chine width to depth ratios (Fig. 6a, Shales and Marls) stage I channels are the only ones that exhibit a significant difference from the other evolutionary stages. This is confirmed by one-way ANOVA and post-hoc Tukey-Kramer statistical analysis $(P<0.05)$. For Chines located in the Lower Greensand unit, Fig. $6 \mathrm{~b}$ suggests that both stages I and III differ from the other stages, an observation that is also statistically upheld $(P<0.05)$. The fact that width to depth ratios do not vary significantly from stages II-V (with the exception of stage III in the Lower Greensand) is not surprising. Following the initial drop in the width to depth ratio induced by stage II downcutting, the Chines maintain similar width and depth proportions due to the continued incision and the onset of mass-wasting (Fig. 3).

The bank slope data for each CEM stage (Fig. 6b) is not as straightforward, as the data for each stage exhibit a larger range, so many of the box-plots overlap. One-way ANOVA was again performed, supplemented by post-hoc Tukey-Kramer multiple analysis of means $(P<0.05)$. Table 1 reveals that there are groups of slope means that are not statistically different from one another, but again this is not surprising given that similar processes are operating on bank slopes located within quite different stages of evolution.

Although only a few of the CEM stages can be discriminated on the basis of bank slope (e.g. stages I and III of the Shales and Marls) or width to depth ratios (e.g. stages I and III of the Lower Greensands) alone, a synthesis of all the available evidence (Table 2) indicates that the use of morphometric criteria, particularly the bank slope categories introduced in Fig. 7, in conjunction with cross-section profiles and field observations of active processes, can be used to robustly discriminate each of the stages of Chine evolution. Table 2, together with Figs. 5 and 7 therefore form integral components of the CEM that enable user's to confidently allocate reaches into specific CEM classes.

\section{Analysis of Chine stability}

As described previously the relative rates of cliff recession (external control) and knickpoint migration (internal control) determine whether a specific Chine will grow, decay, or retain a dynamically constant length. Here we use a combination of empirical data analysis and analytical modelling to constrain these rates for a range of selected Chines.

\subsection{Cliff recession rates}

The soft cliffs of the southwest coast of the Isle of Wight have been the subject of numerous studies of cliff retreat rates (May, 1966;
Hutchinson et al., 1981; Posford-Duvivier, 1997), failure mechanisms (Hutchinson, 1987), sediment output to the littoral environment (Bray et al., 2004) and management strategies (McInnes, 1983; Barrett, 1985; McInnes, 1994). These studies suggest that long-term historical (last 150 years) rates of cliff retreat, although variable, are of the order $0.5 \mathrm{~m} \mathrm{a}^{-1}$. However, few studies have treated this coastline as a holistic unit (e.g. Halcrow, 1997) and investigated rates and modes of failure along the continuous section as in the approach adopted by Pierre and Lahousse (2006) and Pierre (2006) for cliff sections in northern France. Such an approach is required as rates of cliff retreat along the coast vary considerably, but details of the specific changes that are local to each Chine are required to define their respective stabilities.

Contemporary rates of cliff retreat were quantified herein by analysing sequences of geo-referenced historical (1946, 1956, 1988 and 2001) aerial photographs in ArcGIS, with resolutions of 1:10,000 for the 1946 and 1955 images and 1:5000 for the 1988 and 2001 images. The photos were geo-referenced using a second order polynomial transformation; the average root mean squared error of the residuals from the fits between maps was $1.2 \mathrm{~m}$. Although this is a reasonably high absolute error, it must be pointed out that the aerial images (especially 1946 and 1956) were of a relatively coarse resolution, which hindered precise location of control points. Nevertheless, over the 55 year study period this error is acceptable, since it results in a maximum propagated error (where at a given location aerial images are erroneously referenced to the maximum extent in the same direction, i.e. an offset of $4.8 \mathrm{~m}$ ) of only $\pm 0.1 \mathrm{~m} \mathrm{a}^{-1}$. The cliff positions were digitised on each set of aerial photos using the cliff foot as the delineation and a baseline, an arbitrary in-land polyline offset from one of the cliff lines, was created. The Digital Shoreline Analysis System (DSAS) developed by Thieler and Danforth (1994), was then used to cast transects from the baseline every $100 \mathrm{~m}$ along the coast. DSAS uses these transects to create a series of statistics describing the magnitude, rates and associated errors of change along the coast across each transect (Fig. 8).

For ease of analysis and comparison to prior studies, the coast was broken down into five units, based on geological setting and geographical locations (Fig. 8). The rates derived from the analysis (Table 3) are consistent with the historical rate of $0.5 \mathrm{~m} \mathrm{a}^{-1}$ cited above. The lowest contemporary rate of cliff retreat $(0.3 \pm$ $0.08 \mathrm{~m} \mathrm{a}^{-1}$ ) is located in Section 5 , which comprises the more resistant Gault Clay undercliff. However, historical data indicates Section 1 as having the lowest rate of retreat $\left(0.34 \mathrm{~m} \mathrm{a}^{-1}\right)$, which is very close to the 1946-2001 estimate of $0.34 \pm 0.01 \mathrm{~m} \mathrm{a}^{-1}$, suggesting that the chalk geology is associated with a consistent long-term rate of retreat. This is presumably because the largescale landslips that create episodic rates of retreat tend not to occur within the chalk outcrops. In contrast reaches located in the softer Wealden formations have higher rates of historical (last 150 years) ( 0.54 and $0.47 \mathrm{~m} \mathrm{a}^{-1}$ for Sections 2 and 3, respectively), and contemporary (1946-2001) rates of retreat $(0.58 \pm 0.07$ and $\left.0.59 \pm 0.08 \mathrm{~m} \mathrm{a}^{-1}\right)$. Recession is most rapid in Section 4, which is the section found in the Greensand geology and encompassing Whale Chine. The historical rate (1866-1995) is estimated at $0.6 \mathrm{~m} \mathrm{a}^{-1}$ here, with the recent rate (1946-2001) slightly higher at $0.68 \pm 0.16 \mathrm{~m} \mathrm{a}^{-1}$. These rates are consistent with the view that the Greensand geology is the most erodible unit along this coast (White, 1921; Daley and Insole, 1984; Insole et al., 1998).

\subsection{Knickpoint migration rates}

A wide body of literature (Sklar and Dietrich, 1998; Stock and Montgomery, 1999; Whipple and Tucker, 1999; Bishop et al., 2005; Harbor et al., 2005; Crosby and Whipple, 2006; Wobus et al., 2006; Berlin and Anderson, 2007) has used stream power equations 

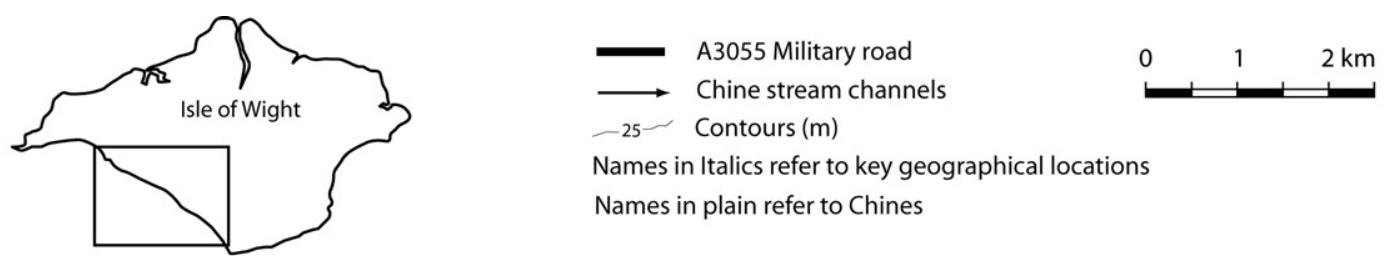

Names in Italics refer to key geographical locations

Names in plain refer to Chines
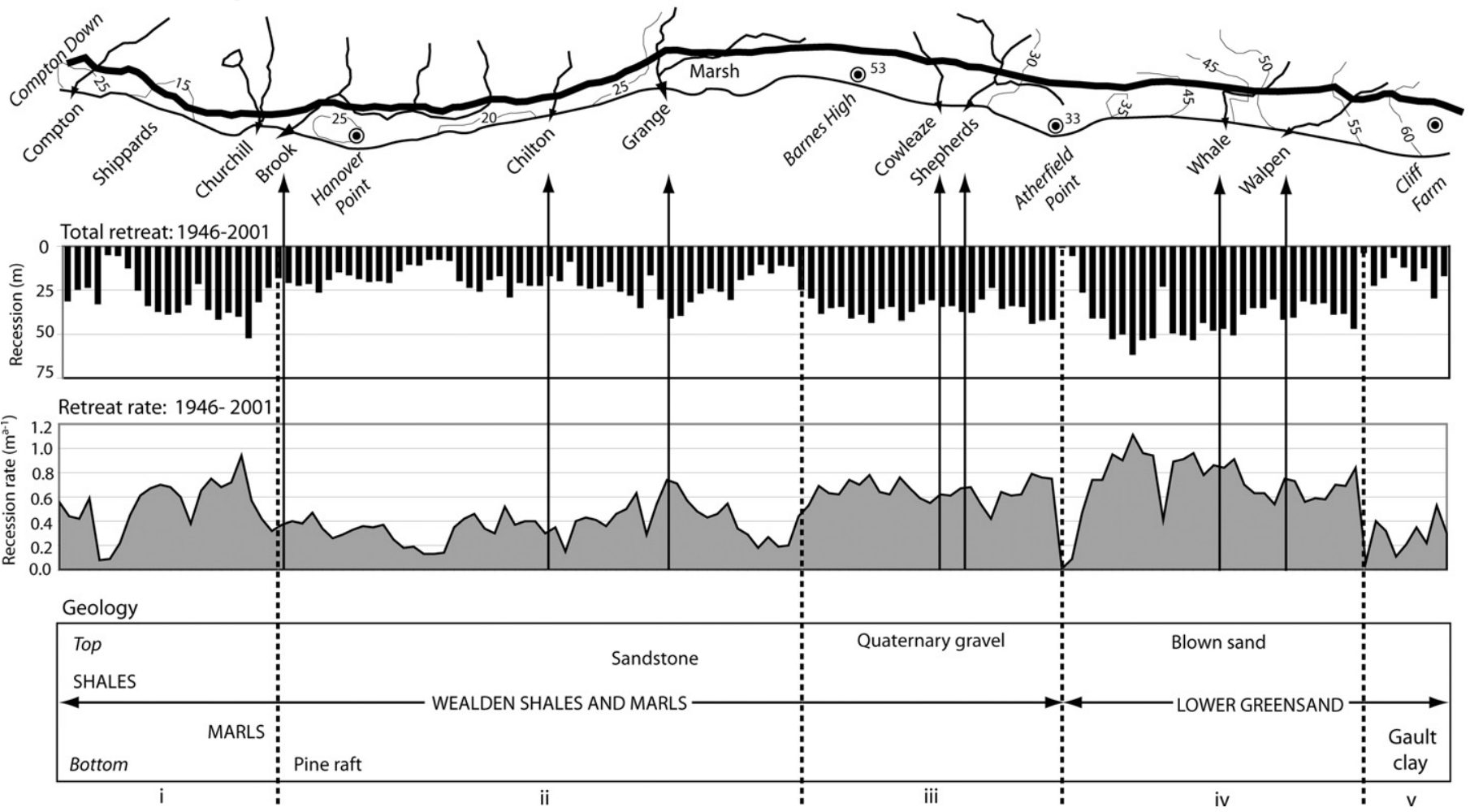

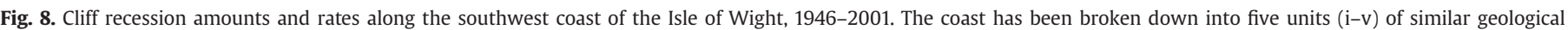
composition.

representing detachment-limited erosion to characterise bedrock channel incision rates:

$E=k A^{m} S^{n}$

where $E=$ erosion rate $\left(\mathrm{m} \mathrm{a}^{-1}\right), A=$ contributing drainage area $\left(\mathrm{m}^{2}\right)$, $S=$ the local channel slope, $m$ and $n$ are dimensionless exponents and $k=$ erosion coefficient (which has dimensions, $\mathrm{L}^{(1-2 \mathrm{~m})} / \mathrm{T}$, that depend on the value of $m$ ). Here we assume that knickpoint migration rates can be equated to $E$, enabling us to use Eq. (1) to simulate knickpoint erosion rates for specific Chines (Crosby and Whipple, 2006; Berlin and Anderson, 2007). However, careful parameterisation of the coefficients $k, m$, and $n$ is required and we now outline the method by which this is achieved.

Many authors (e.g. Snyder et al., 2000; Whipple, 2001; Duvall et al., 2004) have shown that stream profiles can be described as a power function of drainage area using:

$S=k_{S} A^{-\theta}$

where the exponent $\theta=m / n$ and $k_{s}$ is a coefficient (which has dimensions, $L^{2 \theta}$, which depend on the value of $\theta$ ). Thus a simple regression between local slope and contributing drainage area directly yields estimates of both $\theta$, which is referred to as the concavity index, and $k_{s}$.

It is important to note that Eq. (2) is applied only to the undisturbed streams upstream of the Chines, which exhibit mildly concave-up profiles devoid of knickzones. The details of the slope-area analysis employed to determine $\theta$ and $k_{\mathrm{s}}$ are now discussed.

\subsubsection{Slope-area analysis}

Slope-area analysis was undertaken for five of the main six Chine catchments (Fig. 1) draining to the southwest coast. Cowleaze Chine was excluded because the Chine stream, and hence drainage area, is known to have been captured by Shepherds Chine. To carry out the analysis, Ordnance Survey PROFILE data at $10 \mathrm{~m}$ resolution was used in ArcGIS to construct a DEM of the southwest coast. The DEM was sink filled and then, using Arc Hydro Tools (a set of watershed analysis tools developed by the University of Texas and ESRI), watersheds were delineated and contributing areas calculated. A raster of local (10 m) slope was also calculated from the DEM. Trunk streams were defined as polylines and these were used in conjunction with a profile extract tool to define elevation and local slope profiles along each trunk stream in a manner analogous to that employed by Bishop et al. (2005). Using a combination of field observations, the local slope plots and the long profiles, the locations of Chine headcuts were then identified. Analysis of plots of local slope along the trunk streams revealed mildly concaveup long profiles $(\theta=0.37 \pm 0.07, n=5)$ upstream of the Chines.

Slope-area plots have been used successfully to constrain the values of $m$ and $n$ in the stream power law by numerous authors (Howard and Kerby, 1983; Stock and Montgomery, 1999; Whipple and Tucker, 1999, 2002; Tucker and Whipple, 2002; Duvall et al., 2004; Crosby and Whipple, 2006; Wobus et al., 2006; Berlin and Anderson, 2007). In these studies the local slope of a cell in a DEM and the contributing area flowing to that cell is calculated for all cells in the drainage basin and then plotted on log-log axes. The data usually reveal a scaling break at the process transition from hillslope to fluvial regimes, although this may be obscured by the considerably scattered 

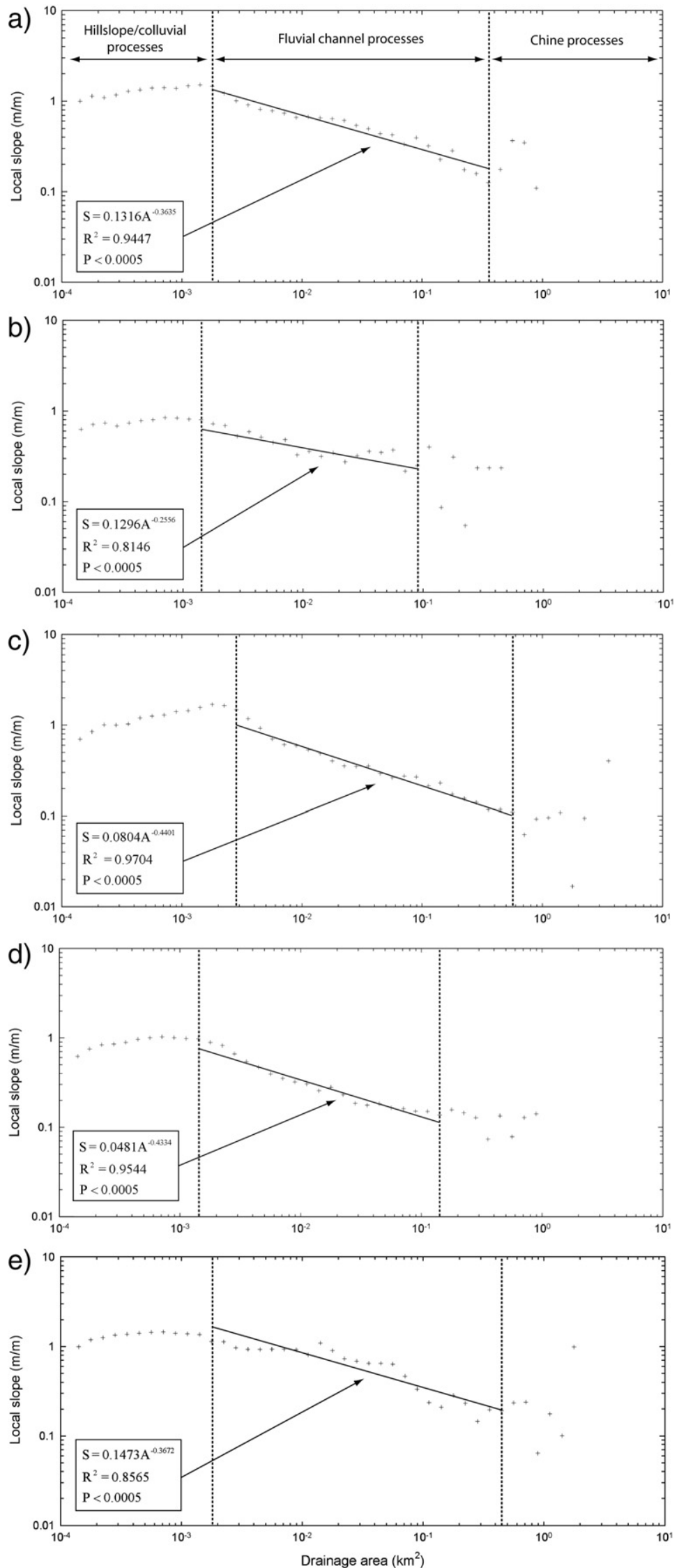

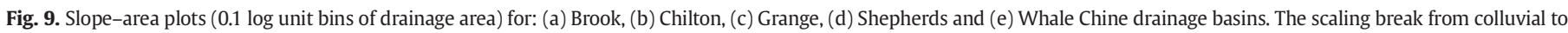

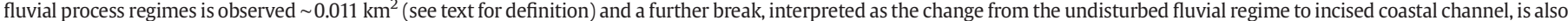

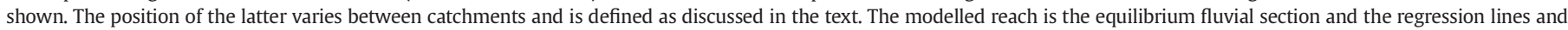

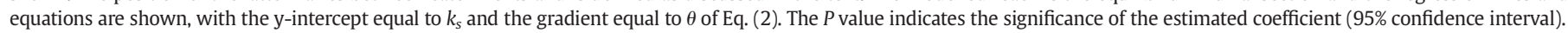


nature of the data. Some smoothing of the data is, therefore, normally needed and there are several methods to achieve this (Wobus et al., 2006). We employed log-bin averaging, which consists of averaging the logarithm of local slopes in defined log-bins of drainage area (Whipple and Tucker, 1999). To determine a suitable bin size, a range of values were investigated using data from Shepherds Chine. The largest bin size of $0.1 \mathrm{log}$ units of drainage area was eventually selected and used in all subsequent analyses, as this allowed the best visible analysis of the scaling breaks that occur in the log-bin averaged data for the Chines. Moreover, the choice of bin size had little effect on the form of the resulting slope-area regression equations (see below), while the associated $R^{2}$ values increased significantly from 0.87 $(n=355, P<0.0005)$ to $0.95(n=39, P<0.0005)$ as bin size was increased from 0.01 to $0.1 \log$ units of drainage area.

Fig. 9 clearly reveals the scaling break $\left(A \approx 0.01 \mathrm{~km}^{2}\right)$ delineating the transition from hillslope to fluvial process dominated domains. Perhaps more interestingly for this study is an apparent second scaling break, where the broadly inversely log-linear trend defining the fluvial regime crosses a threshold at $\sim 0.1-0.5 \mathrm{~km}^{2}$ and scatters considerably. In the published studies this break normally represents a transition from bedrock to alluvial channel processes (Snyder et al. 2000; Duvall et al. 2004). However, here it is interpreted as representing a transition from the equilibrated fluvial regime to the unstable Chine process dominated parts of the basin downstream.

Defining the precise locations of the two scaling breaks requires careful consideration because to estimate $k_{s}$ and $\theta$ the slope-area data must be regressed only within the fluvial regime (Howard and Kerby 1983; Whipple and Tucker 1999; Stock and Montgomery 1999; Whipple and Tucker 2002; Tucker and Whipple 2002; Wobus et al. 2006; Berlin and Anderson 2007). Although the upper scaling break is obvious, as the divergent hillslope process part of the area-slope plot exhibits a classic convex up shape, the scatter at the fluvial to Chine process boundary requires a formal method to define its position. This was achieved using the local slope plots extracted from the DEM to define the headcut positions of the Chines following Bishop et al. (2005). Using the contributing drainage area map and the trunk stream polylines derived previously, the contributing area at the head of each Chine could then be defined and the lower scaling break placed accordingly.

The scaling breaks, area-slope plots and resulting regressions are illustrated in Fig. 9. It has been shown that for detachment-limited bedrock channels $\theta$ is typically $\sim 0.5$ (Whipple and Tucker, 1999, 2002; Snyder et al., 2000; Kirby and Whipple, 2001). Our values (see Table 3) are broadly consistent with this, indeed the derived values of $\theta$ and $k_{s}$ both fall within the respective ranges cited in the literature (Hancock et al., 1998; Tucker and Bras, 1998; Stock and Montgomery, 1999; Whipple et al., 1999, 2000; Snyder et al., 2002). Finally, it is necessary to partition the concavity index into specific values of $m$ and $n$. This was achieved by simply assuming $n=1$ for consistency with the 'stream power' law form of Eq. (1). The slope exponent (n) is in fact known to depend on the dominant erosion process; Whipple et al. (2000) arguing that its value varies between $\sim 2 / 3$ and $\sim 5 / 3$. Although Tucker and Whipple (2002) note that the behaviour of landscape evolution models varies critically with the choice of $\mathrm{n}$, they found that $n=1$ induces parallel retreat of stream profiles, consistent with our observations that Chine knickpoints maintain marked steps as they migrate upstream.

\subsubsection{Estimating the parameter $k$}

Although the preceding provides a means to estimate $k_{s}$, determination of $k$ requires further analysis. The approaches used in past studies have ranged from using brute force parameter searches (Berlin and Anderson, 2007) to assuming that if a change in elevation in a tectonically active area is equal to uplift minus erosion, with known rates of uplift and $A^{m}$ and $S^{n}, k$ can be estimated (Duvall et al., 2004). However tectonic adjustment can be assumed negligible on the
Table 3

Overview of computed key erosion rate metrics and associated erosion parameters for selected Chines

\begin{tabular}{|c|c|c|c|c|c|c|}
\hline Chine & $\begin{array}{l}\mathrm{DA} \\
\left(\mathrm{km}^{2}\right)\end{array}$ & $\begin{array}{l}\text { CRR } \\
\left(\mathrm{km}^{2}\right)\end{array}$ & $\begin{array}{l}\text { Mean KPE for } 1703 \\
\text { to } 2004\left(\mathrm{~m} \mathrm{a}^{-1}\right)\end{array}$ & $\theta$ & $k$ & $\begin{array}{l}A_{\mathrm{cr}} \\
\left(\mathrm{km}^{2}\right.\end{array}$ \\
\hline \multicolumn{7}{|c|}{ Wealden Shales and Marls } \\
\hline Brook & 5.38 & 0.44 & 0.92 & 0.36 & $2.7 \times 10^{-2} \mathrm{~m}^{0.28} \mathrm{yr}^{-1}$ & 0.8 \\
\hline Chilton $^{\mathrm{a}}$ & 1.37 & 0.45 & 0.72 & 0.26 & $3.1 \times 10^{-1} \mathrm{~m}^{0.48} \mathrm{yr}^{-1}$ & 0.20 \\
\hline Grange & 12.9 & 0.55 & 0.98 & 0.44 & $6.1 \times 10^{-3} \mathrm{~m}^{0.12} \mathrm{yr}^{-1}$ & $4 .($ \\
\hline Shepherds & 11.7 & 0.62 & 0.96 & 0.43 & $1.1 \times 10^{-2} \mathrm{~m}^{0.14} \mathrm{yr}^{-1}$ & 4.5 \\
\hline Mean & 7.86 & 0.52 & 0.95 & 0.41 & $1.5 \times 10^{-2} \mathrm{~m}^{0.18} \mathrm{yr}^{-1}$ & 3.15 \\
\hline SD & \pm 5.45 & \pm 0.09 & \pm 0.03 & \pm 0.04 & \pm 0.01 & \pm 1.9 \\
\hline \multicolumn{7}{|c|}{ Lower Greensand } \\
\hline Whale & 2.24 & 0.8 & 1.38 & 0.37 & $4.9 \times 10^{-2} \mathrm{~m}^{0.26} \mathrm{yr}^{-1}$ & 0.7 \\
\hline
\end{tabular}

Error bars associated with the mean rates are equal to one standard deviation. The coefficient, $\theta$, of the regression analysis was significant $(P<0.0005)$ at the $95 \%$ confidence interval. Key to metrics: DA - Drainage area, CRR - Cliff retreat rate, KPE - knickpoint erosion rate, $\theta$ - Concavity index (slope exponent), $k-$ Erodibility coefficient, $A_{\mathrm{cr}}-$ Critical drainage area (for specified CRR).

a The data for Chilton Chine was excluded from the calculations of the mean and standard deviations (see text for details).

Isle of Wight (Shennan, 1989; Long and Tooley, 1995; Edwards, 2001) so it would perhaps be more appropriate to recast Eq. (1) as:

$k=\frac{E}{A^{m} S^{n}}$

However, Eq. (3) involves the rate of knickpoint erosion (E), which is of course the unknown we are seeking to model. However, $E$ can be estimated directly by identifying the locations of contemporary knickpoints and hence the distance that they must have migrated upstream since forming at the Chine outlet, and estimating the date of knickpoint formation. Prior to outlining how this is achieved, we note the evident circularity in determining $k$ to predict $E$ via means of an independently determined estimate of $E$. However, rather than employing the latter in the analysis of Chine stability, we retain a modelling approach because it leaves open the possibility of simulating other Chines located on this coast but not included in the analysis here (albeit with a model that employs a calibrated value of $k$ ).

The issue of identifying knickpoint locations has already been discussed in the context of the slope-area modelling, but for this specific analysis we employed higher $(2 \mathrm{~m})$ resolution 2004 LIDAR data to derive the local slope profiles for each Chine following the methodology of Bishop et al. (2005) (Fig. 10). The dates for which each knickpoint formed were then equated to large-scale cliff recession events that are known to be associated with knickpoint formation. However, direct evidence of the timing of these events is unavailable. Based on the presence of two major knickpoints in all the Chines (Fig. 10), it seems likely that they were initiated by common events. We assume that formative cliff retreat events would have occurred at, or some time soon after, extreme storms affecting essentially the entire coastline. The rationale behind such a claim is that increased cliff toe erosion will occur due to severe wave attack, perhaps associated with marine surges, and the moisture content of the cliff material will also be increased by the storm, making them prone to failure (Halcrow, 1997; Bird, 2000).

Regarding candidate formative storm events, West (2007) offers a comprehensive review of storms and storm surges that have affected Chesil Beach and Hurst Spit (located just northwest of the southwest coast of the Isle of Wight) since 1014, using a range of historical sources. In fact there have been no storms of the magnitude required to initiate largescale cliff failure and create major knickpoints during the recent period for which direct observations of cliff recession in our study area are available (i.e. 1946-2001). The two largest storm events to affect the south coast in recent history occurred in 1703 and 1824 (Lyell, 1835; Lamb and Frydendahl, 1991; Legg 1999; West, 2007). Consequently the two most 

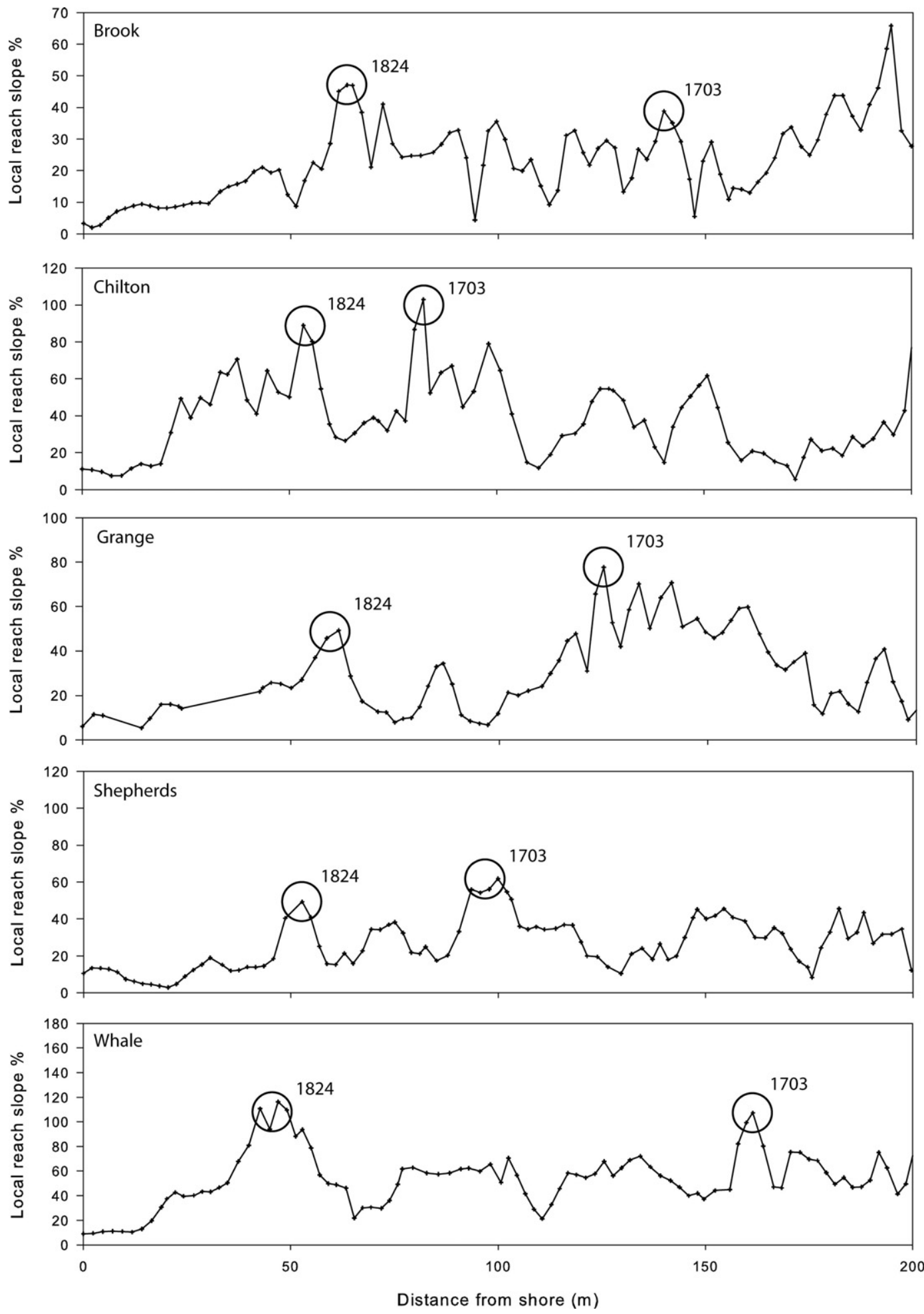

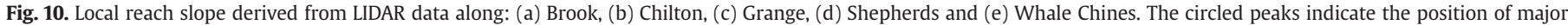

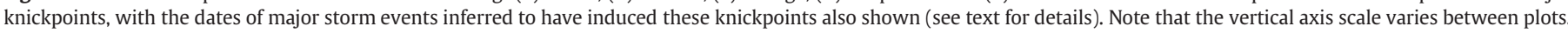

downstream knickpoints located in each of the Chines from the analysis above, are herein assumed to have been formed in 1703 and 1824 (Fig. 10).

To calculate the total knickpoint erosion (TKPE), the cliff retreat amount (TCR) over the given period must also be accounted for so that:

$\mathrm{TKPE}=\left(\frac{\mathrm{TCR}+\mathrm{KPE}}{t}\right)$

where KPE is the present magnitude of retreat as shown in Fig. 8 and $t$ is the total time since the storm event. The values of TCR were estimated from the cliff retreat rates (CRR) calculated from the analysis undertaken in Section 5.1 and which are shown in Table 3.

Using the values for $m, n$, and $E$ derived in the preceding and solving Eq. (3) yields values of $k$ for each Chine as shown in Table 3. From the knickpoint erosion analysis and the background geological review it is clear that the Lower Greensand lithology (Whale Chine) erodes at a relatively faster rate than the Wealden beds $\left(1.38 \pm 0.35 \mathrm{~m} \mathrm{a}^{-1}\right.$ compared to $\left.0.89 \pm 0.12 \mathrm{~m} \mathrm{a}^{-1}\right)$. It makes intuitive sense, therefore, that $k$ should be larger (i.e. more erodible) for the Lower Greensand, as is confirmed in 


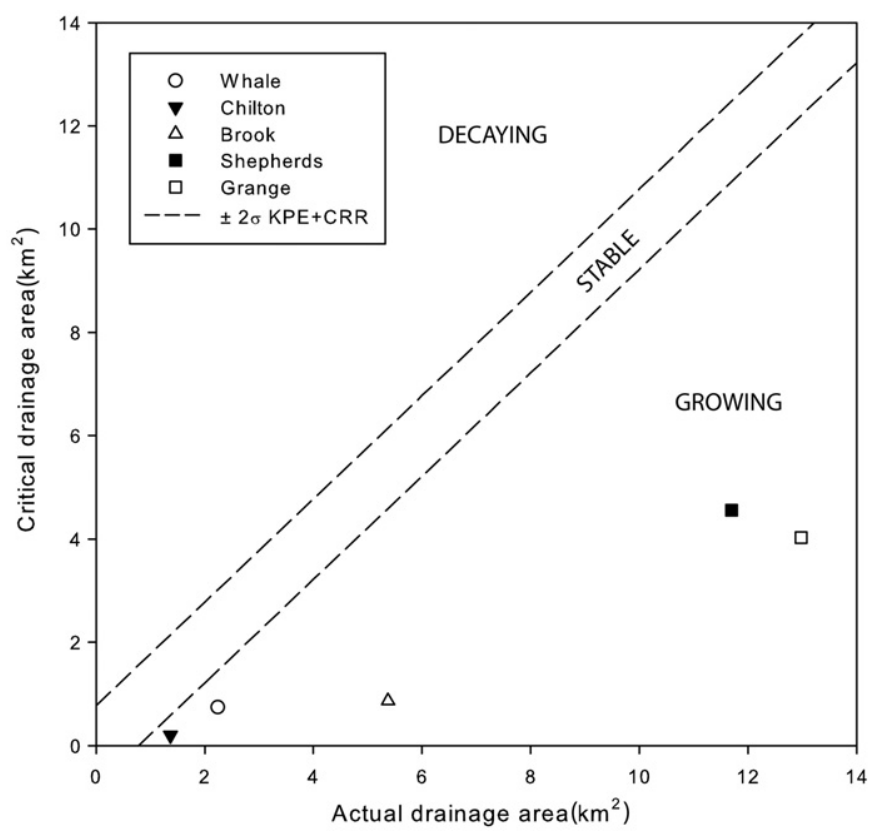

Fig. 11. Relative stability of selected Chines on the Isle of Wight. The uncertainty bands defining 'stable' features were calculated as \pm two times the combined standard deviation of cliff recession rate (CRR) and knickpoint erosion rate (KPE) as defined in Table 3.

Table 3. The value of $k$ derived for Whale Chine $\left(4.9 \times 10^{-2} \mathrm{~m}^{0.26} \mathrm{a}^{-1}\right)$, is considerably higher than the mean for those in the Wealden beds $\left(1.5 \times 10^{-2} \pm 0.04 \mathrm{~m}^{0.18} \mathrm{a}^{-1}\right)$. Note that Chilton Chine was considered an anomaly for this part of the analysis as it has a very small drainage area (the upper parts have almost certainly been re-routed through Grange Chine).

\subsection{Relative stability of contemporary Chines}

The derived values of cliff retreat occurring at the mouth of each individual Chine (Fig. 8) and the knickpoint erosion parameters calculated above (Table 3), can be combined in a plot (Fig. 11) showing the relative stability, where here the term stability refers to a dynamically constant Chine length, of each of the selected Chines. It is apparent that currently all of the Chines have the capacity to maintain headward erosion to the extent where, if conditions allow, they will grow. Indeed, by recasting Eq. (1) as:

$A_{\mathrm{cr}}=m \sqrt{\left(\frac{E}{k S^{n}}\right)}$

the critical drainage area $\left(A_{\mathrm{cr}}\right)$ required to sustain individual Chines in a state of stability or extension can be estimated (Table 3 ). This reveals that, due to their erodible lithology and steep catchment slopes, the Chines evidently require only small drainage areas $\left(>\sim 3 \mathrm{~km}^{2}\right)$ to maintain their stability under existing rates of sea-cliff recession.

\section{Conclusions}

Through detailed assessment of contemporary Chine processes and morphologies, we herein identify a series of archetypal stages of Chine channel evolution. Chines appear to be initiated in instances where river channels flowing over cliffed coasts have sufficient energy to incise through the cliffs. The resulting knickpoint may then subsequently migrate headwards, potentially initiating a phase of Chine growth. We used SFTS to develop a five-stage conceptual model that sets out the sequence of adjustments experienced by an initially undisturbed channel that is destabilised by the passage of these headward migrating knickpoints. For the case of growing Chines, these phases of evolution correspond to: (I) the pre-disturbance channel, (II) rapid incision which may be sufficiently large to trigger side-wall mass-wasting that then leads to, (III) phases of widening, (IV) reductions in widening rates and the onset of bed deposition, due to the supply of large volumes of colluvium from the Chine side-walls, and $(\mathrm{V})$ a secondary phase of incision as the channel cuts through the colluvial infills. For decaying Chines, in which the knickpoint retreat rate is less than the cliff retreat rate, the features do not pass through the sequential stages of development. Instead evidence of latter stage morphology is destroyed as cliff retreat truncates the feature. The model recognises and incorporates the possibility that an incised coastal channel system may follow one of many developmental pathways. Importantly, we have demonstrated that a range of specific morphometric indices, when employed in conjunction with field interpretations of active processes, can be used to reliably classify Chine cross-sections into one of the five postulated stages of development. As such, we believe that our conceptual model is a useful tool that can be employed to predict evolutionary trajectories of these features.

Our research has also emphasised the importance of determining whether a Chine is in a state of growth or decay. To evaluate this aspect, we employed a simple Chine stability criterion based on determining the relative rates of cliff retreat (which are here quantified via analysis of historical aerial photographs) and knickpoint recession. We estimated the latter by parameterising a detachmentlimited stream power based erosion law for bedrock channels, using DEM data and geomorphological analysis for a total of five Chine catchments. The model predictions indicate that, under contemporary rates of sea-cliff recession $\left(\sim 0.5 \mathrm{~m} \mathrm{a}^{-1}\right)$, only relatively small drainage areas $\left(\sim 3 \mathrm{~km}^{2}\right)$ are required to generate sufficient runoff to maintain the Chines in a state of equilibrium or growth. This is a significant finding that, given the habitat value of these features, provides some reassurance that the Chines are sustainable landscape features, at least in the immediate to mid-term. We are currently engaged in research that is applying quantitative modelling to investigate in more detail both the historical and future trajectories of Chine evolution under a range of climate and sea-level (cliff recession) change scenarios.

In closing, we note that the conceptual model of incised coastal channel development presented herein has been developed based on the specific context of the Chines of the Isle of Wight, but it is likely to be transferable to other incised coastal channel or gully systems that cut through soft sea cliffs, albeit with the likely need to undertake modifications to the diagnostic criteria used to identify stages of channel evolution in each new specific environment.

\section{Acknowledgements}

JL gratefully acknowledges $\mathrm{PhD}$ funding from the England and Wales Environment Agency and the School of Geography, University of Southampton. LIDAR data were provided courtesy of the Channel Coastal Observatory. Aerial photographs were provided by the Isle of Wight record office and the Centre for the Coastal Environment. We thank Jonathan Phillips and Michael Fullen for the helpful and constructive reviews and Takashi Oguchi for the editorial advice.

\section{References}

Barber, K.E., 1987. Wessex and the Isle of Wight - Field Guide. Quaternary Research Association, Cambridge. 180 pp.

Barber, T., 1834. Picturesque Illustrations of the Isle of Wight. Simpkin and Marshall, London. 110 pp.

Barrett, M.G., 1985. Isle of Wight - shoreline erosion and protection. Conference on Problems associated with the Coastline, Newport, Isle of Wight, UK, p. 8.

Berlin, M.M., Anderson, R.S., 2007. Modeling of knickpoint retreat on the Roan Plateau, western Colorado. Journal of Geophysical Research 112,1-16. 
Bird, E., 1997. The Shaping of the Isle of Wight. Cromwell Press, Wiltshire. 175 pp.

Bird, E.C.F., 2000. Coastal Geomorphology - An Introduction. John Wiley and Sons, Chichester. $322 \mathrm{pp}$.

Bishop, P., Hoey, T.B., Jansen, J.D., Artza, I.L., 2005. Knickpoint recession rate and catchment area: The case of uplifted rivers in Eastern Scotland. Earth Surface Processes and Landforms 30, 767-778.

Bowers, B., Bowers, K., 1996. Michael Faraday's geological notes on the Isle of Wight Notes and Records of the Royal Society of London 50, 65-74.

Bray, M.J., Carter, D.J., Hooke, J.M., 2004. Standing Conference on Problems Associated with the Coastline - Coastal Sediment Transport Study: West, South and East Isle of Wight. University of Portsmouth.

Brookes, A. (Ed.), 1988. Channelized Rivers: Perspectives for Environmental Management. John Wiley and Sons Ltd, Chichester, U.K. 336 pp.

Burkard, M.B., Kostaschuk, R.A., 1995. Initiation and evolution of gullies along the shoreline of Lake Huron. Geomorphology 14, 211-219.

Clark, P.U., Mix, A.C., 2002. Ice sheets and sea level of the Last Glacial Maximum. Quaternary Science Reviews 21,1-7.

Crosby, B.T., Whipple, K.X., 2006. Knickpoint initiation and distribution within fluvial networks: 236 waterfalls in the Waipaoa River, North Island, New Zealand. Geomorphology 82, 16-38.

Daley, B., Insole, A., 1984. The Isle of Wight. Geologist's Association Guide. The Geologist's Association, London. 36 pp.

Darby, S.E., Simon, A., 1999. Incised river channels: Processes, forms, engineering and management. Wiley, Chichester. $424 \mathrm{pp}$.

Duvall, A., Kirby, E., Burbank, D.W., 2004. Tectonic and lithologic controls on bedrock channel profiles and processes in coastal California. Journal of Geophysical Research 109.

Edwards, R.J., 2001. Mid- to late Holocene relative sea-level change in Poole Harbour, southern England. Journal of Quaternary Science 16, 221-235.

Emery, K.O., Kuhn, G.G., 1982. Sea cliffs - their processes, profiles, and classification. Geological Society of America Bulletin 93, 644-654.

Fitton, W.H., 1836. On the Strata below the Chalk. Transactions of the Geological Society of London Series 2.

Fitton, W.H., 1847. A stratigraphical account of the section from Atherfield to Rocken End, on the south-west coast of the Isle of Wight. Quarterly Journal of the Geological Society 3, 289-327.

Flint, K.E., 1982. Chines on the Isle of Wight: channel adjustment and basin morphology in relation to cliff retreat. The Geographical Journal 148, 225-236.

Greig, S.M., Sear, D.A., Carling, P.A., 2005. The impact of fine sediment accumulation on the survival of incubating salmon progreny: implications for sediment management. Science of the Total Environment 344, 241-258.

Halcrow, 1997. Isle of Wight Shoreline Management Plan. Report to Isle of Wight Council and Environment Agency.

Formation, evolution and stability of coastal cliffs - status and trends. In: Hampton, M.A. Griggs, G.B. (Eds.), USGS Professional paper, vol. 1693.129 pp.

Hancock, G.S., Anderson, R.S., Whipple, K., 1998. Bedrock erosion by streams: beyond stream power. In: Tinkler, K.J., Wohl, E. (Eds.), Rivers Over Rock: Fluvial Processes in Bedrock Channels. AGU, Washington DC, pp. 35-60.

Harbor, D., Bacastow, A., Heath, A., Rogers, J., 2005. Capturing variable knickpoint retreat in the Central Appalachians, USA. Geografia Fisica e Dinamica Quaternaria 28, 23-36.

Howard, A.D., Kerby, G., 1983. Channel changes in badlands. Geological Society of America Bulletin 94, 739-752.

Howe, M.A., 2002. A review of the coastal soft cliff resource in Wales, with particular reference to its importance for invertebrates. CCW Natural Science Report No. 02/5/1

Hutchinson, J.N., 1987. Some coastal landslides of the southern Isle of Wight. In: Barber, K.E. (Ed.), Wessex and the Isle of Wight: Field guide. Quaternary Research Association, pp. 123-135.

Hutchinson, J.N., Chandler, M.P., Bromhead, E.N., 1981. Cliff recession on the Isle of Wight SW Coast. Proceedings of the 10th International Conference on Soil Mechanics and Foundation Engineering, Stockholm, pp. 429-434.

Insole, A., Daley, B., Gale, A., 1998. The Isle of Wight. Geologists' Association Guide. Geologists' Association, London. 132 pp.

Kirby, E., Whipple, K., 2001. Quantifying differential rock-uplift rates via stream profile analysis. Geology 29, 415-418.

Lamb, H.H., Frydendahl, K., 1991. Historic storms of the North Sea, British Isles and Northwest Europe. Cambridge University Press, Cambridge. 216 pp.

Lambeck, K., 1991. Glacial rebound and sea-level change in the British Isles. Terra Nova 3, 379-389.

Legg, R., 1999. Bridport and Lyme Regis: The Story of Dorset's Western Coast. Dorset Publishing Company. 192 pp.

Long, A.J., Tooley, M.J., 1995. Holocene sea-level and crustal movements in Hampshire and Southeast England, United Kingdom. Journal of Coastal Research 17, 299-310.

Lyell, C., 1835. Principles of Geology. John Murray, London.

May, V.J., 1966. A preliminary study of recent coastal changes and sea defences in southeast England. Southampton Research Series in Geography 3, 3-25.

McInnes, R.G., 1983. The threat to highways from coastal erosion. The Highway Engineer 2-7.

McInnes, R.G., 1994. A Management Strategy for the coastal Zone, South Wight Borough Council.

Nicholls, R.J., 1987. Evolution of the upper reaches of the Solent river and the formation of Poole and Christchurch bays. In: Barber, K.E. (Ed.), Wessex and the Isle of Wight Field Guide. Quaternary Research Association, Cambridge, pp. 99-114.

Pierre, G., 2006. Processes and rate of retreat of the clay and sandstone sea cliffs of the northern Boulonnais (France). Geomorphology 73, 64-77.

Pierre, G., Lahousse, P., 2006. The role of groundwater in cliff instability: an example at Cape Blanc-Nez (Pas-de-Calais, France). Earth Surface Processes and Landforms 31, 31-45.
Posford-Duvivier, 1997. Standing Conference on Problems Associated with the Coastline Research Project. Sediment Inputs to the Coastal System. Phase 2: Cliff Erosion.

Schumm, S.A., Harvey, M.D., Watson, C.C., 1984. Incised Channels: Morphology Dynamics and Control. Water Resources Publications, Chelsea, Michigan. 200 pp.

Schumm, S.A., Phillips, L., 1986. Composite channels of the Canterbury Plain, New-Zealand - a Martian analog. Geology 14, 326-329.

Shennan, I., 1989. Holocene crustal movements and sea-level changes in Great Britain. Journal of Quaternary Science 4, 77-89.

Shennan, I., Horton, B., 2002. Holocene land- and sea-level changes in Great Britain. Journal of Quaternary Science 17, 511-526.

Simon, A., 1989. A model of channel response in disturbed alluvial channels. Earth Surface Processes and Landforms 14, 11-26.

Simon, A., Darby, S.E., 1999. The nature and significance of incised channels. In: Darby, S.E. Simon, A. (Eds.), Incised river channels: processes, forms, engineering and management. John Wiley and Sons, Chichester, England, pp. 3-18.

Simon, A., Hupp, C.R., 1986. Channel evolution in modified Tennessee channels Proceedings of the Fourth Federal Interagency Sedimentation Conference. US Government Printing Office, Washington DC, pp. 71-82.

Simon, A., Hupp, C.R., 1992. Geomorphic and vegetative recovery processes along modified stream channels of west Tennessee. US Geological Survey, Nashville, Tennessee.

Simon, A., Rinaldi, M., Hadish, G., 1996. Channel evolution in the loess area of the midwestern United States. Proceedings of the Sixth Federal Interagency Sedimentation Conference. US Government Printing Office, Washington DC, pp. III-86-III-93.

Sklar, L., Dietrich, W.E., 1998. River longitudinal profiles and bedrock incision models: stream power and the influence of sediment supply. In: Tinkler, K.J., Wohl, E. (Eds.) Rivers Over Rock: Fluvial Processes in Bedrock Channels. . Geophysical Monograph Series. AGU, Washington D.C., pp. 237-260.

Snyder, N.P., Whipple, K.X., Tucker, G.E., Merritts, D.J., 2000. Landscape response to tectonic forcing: digital elevation model analysis of stream profiles in the Mendocino triple junction region, northern California. Geological Society of America Bulletin 112, 1250-1263.

Snyder, N.P., Whipple, K.X., Tucker, G.E., Merritts, D.J., 2002. Interactions between onshore bedrock-channel incision and nearshore wave-base erosion forced by eustasy and tectonics. Basin Research 14, 105-127.

Stock, J.D., Montgomery, D.R., 1999. Geologic constraints on bedrock river-incision using the stream power law. Journal of Geophysical Research 104, 4983-4993.

Suren, A.M., Martin, M.L., Smith, B.J., 2005. Short-term effects of high suspended sediments on six common New Zealand stream invertebrates. Hydrobiologia 548, 67-74.

Thieler, E.R., Danforth, W.W., 1994. Historical shoreline mapping (II): application of the Digital Shoreline Mapping and Analysis Systems (DSMS/DSAS) to shoreline change mapping in Puerto Rico. Journal of Coastal Research 10, 600-620.

Tubbs, C., 1999. The Ecology, Conservation and History of the Solent. Packard Publishing Limited, Chichester. 184 pp.

Tucker, G.E., Bras, R.L., 1998. Hillslope processes, drainage density, and landscape morphology. Water Resources Research 34, 2751-2764.

Tucker, G.E., Whipple, K.X., 2002. Topographic outcomes predicted by stream erosion models: sensitivity analysis and intermodel comparison. Journal of Geophysical Research - Solid Earth 107 art. no. 2179.

Velegrakis, A.F., Dix, J.K., Collins, M.B., 1999. Late Quaternary evolution of the upper reaches of the Solent River, Southern England, based upon marine geophysical evidence. Journal of the Geological Society 156, 73-87.

Velegrakis, A.F., Dix, J.K., Collins, M.B., 2000. Late Pleistocene/Holocene evolution of the upstream section of the Solent River. In: Collins, M.B., Ansell, K. (Eds.), Solent Science - A Review. Elsevier Science, Amsterdam, pp. 97-99.

Watson, C.C., Harvey, M.D., Garbrecht, J., 1986. Geomorphic-hydraulic simulation of channel evolution. Proceedings of the 4th Federal Interagency Sedimentation Conference. US Government Printing Office, Washington, DC, pp. 5-21-5-30.

West, I.M., 1980. Geology of the Solent Estuarine System, The Solent Estuarine System: An Assessment of Present Knowledge. NERC publication series C, vol. 22. Natura Environment Research Council, London, pp. 6-18.

West, I.M., 2007. Chesil Beach: Storms and Floods. Geology of the Wessex Coast of Southern England. Internet site: http://www.soton.ac.uk/ imw/chestorm.htm. School of Ocean and Earth Sciences, National Oceanography Centre, Southampton, Southampton University.

Whipple, K.X., 2001. Fluvial landscape response time: how plausible is steady-state denudation? American Journal of Science 301, 313-325.

Whipple, K.X., Tucker, G.E., 1999. Dynamics of the stream-power river incision model: implications for height limits of mountain ranges, landscape response timescales, and research needs. Journal of Geophysical Research - Solid Earth 104, 17661-17674

Whipple, K.X., Tucker, G.E., 2002. Implications of sediment-flux-dependent river incision models for landscape evolution. Journal of Geophysical Research 107 art. no. 2039.

Whipple, K.X., Kirby, E., Brocklehurst, S.H., 1999. Geomorphic limits to climate-induced increases in topographic relief. Nature 401, 39-43.

Whipple, K.X., Hancock, G.S., Anderson, R.S., 2000. River incision into bedrock: mechanics and relative efficacy of plucking, abrasion, and cavitation. Geological Society of America Bulletin 112, 490-503.

White, H.A.O., 1921. A short account of the geology of the Isle of Wight. Natural Environment Research Council, London. $201 \mathrm{pp}$.

Wobus, C.W., Whipple, K., Kirby, E., Snyder, N., Johnson, J., Spyropolou, K., Crosby, B.T. Sheehan, D., 2006. Tectonics form topography: procedure, promise, and pitfalls. In: Willett, S.D., Hovius, N., Brandon, M.T., Fisher, D.M. (Eds.), Tectonics, Climate, and Landscape Evolution: Geological Society of America Special Paper. Penrose Conference Series, vol. 398, pp. 55-74. 